\title{
IMPROVING STRATEGIC ORIENTATIONS FOR PROMOTING HOTEL SERVICES USING AN INTEGRATED ROUGH MAGDM MODEL
}

\author{
James J. H. LIOU ${ }^{*}$, Artūras KAKLAUSKAS ${ }^{2}$, \\ Ming-Tsang $\mathrm{LU}^{3}$, Yen-Ching CHUANG ${ }^{1}$ \\ ${ }^{1}$ Department of Industrial Engineering and Management, National Taipei University of Technology, \\ 1, Sec. 3, Zhongxiao E. Rd., Taipei 10608, Taiwan \\ ${ }^{2}$ Department of Construction Technology and Management, \\ Vilnius Gediminas Technical University, Vilnius, Lithuania \\ ${ }^{3}$ Office of Institutional Research and Assessment, National Taipei University \\ of Technology, 1, Sec. 3, Zhongxiao E. Rd., Taipei 10608, Taiwan
}

Received 23 December 2017; accepted 14 October 2018

\begin{abstract}
This study aims to assist decision makers to improve hotel service performance by developing strategic orientations. Strategic orientations are imprecise and subjective: they vary according to domain experts' opinions and practical experience. This study develops an integrated rough multiple attribute group decision-making (MAGDM) model that supports decision makers to acquire a systematic view of strategic methods for improving performance to the desired level. The model incorporates three methods. First, we use the rough number approach to determine group opinions from the practical experience of domain experts. We then apply the rough decision making trial and evaluation laboratory (DEMATEL)-based analytic network process to develop a rough influential network relation map (RINRM). The rough influential weights based on strategic orientations and their corresponding attributes are calculated. Finally, we use the modified complex proportional assessment of alternatives with gray relations (mCOPRAS-G) and the influential weights to calculate the relationship ratio between performance and aspiration level. Our model flexibly assesses the vagueness involved in decision-making, enabling more objective expert estimation of attributes in subjective surroundings than traditional multiple attributes decision-making models. We use the Taiwanese hotel industry as an empirical case study. Our study provides useful information on how to enhance hotel services and achieve optimal performance based upon expert judgments and the RINRM. The results show that customer orientation is the optimal strategy for hotel service promotion.
\end{abstract}

Keywords: strategic orientation, hotel service performance, multiple attribute group decision making (MAGDM), rough number, rough DEMATEL-based analytic network process (RDANP), modified complex proportional assessment of alternatives with gray relations (mCOPRAS-G).

JEL Classification: C02, C60, D12, D81, L83, O21.

*Corresponding author. E-mail: jamesjhliou@gmail.com

This is an Open Access article distributed under the terms of the Creative Commons Attribution License (http://creativecommons. org/licenses/by/4.0/), which permits unrestricted use, distribution, and reproduction in any medium, provided the original author and source are credited. 


\section{Introduction}

Global competition, coupled with a rapidly changing business environment and increasing service requests, has made hotels more vulnerable to challenges than at any time in the past (Tajeddini \& Trueman, 2014). Hence, it has become of the utmost importance for hotels to be both adaptive and strategic. At the same time, to sustain a competitive advantage and achieve market success, hotels should place strategic orientations at the core of the corporation's competitiveness and extend and enhance the strategic planning of their administrators (Trueman, 2011; Tajeddini \& Trueman, 2014; Tajeddini, Altinay, \& Ratten, 2017). Hence, strategic orientations such as market, entrepreneurial, and interaction orientations are among the most valuable types of capital and are essential to strive effectively in today's global market. Their significance arises from the significance of a strategic orientation in commercial surroundings conditioned by growing economic and global diversity.

Hotels are faced with challenges connected to the ever-growing volume and pace of competition today. Strategy-making activities and marketing in the hotel industry is a serious undertaking and the strategic orientation of services to enhance the organizations' competitive advantages in the service industry has garnered much attention (Noble, Sinha, \& Kumar, 2002; Brower \& Rowe, 2017; Tajeddini \& Trueman, 2014; Tajeddini et al., 2017). To acquire a competitive advantage requires the collective efforts of administrators, along with their group members, to make good decisions and rapidly respond to variations in the commercial surroundings (Yeo, 2007; Jorgensen, 2004). Moreover, to adapt to environmental varies and enhance performance, hotels must be able to respond to uncertainty and embark on strategic planning programs. Therefore, in the face of strong competition in a rapidly-changing market, firms must improve the strategic orientations leading their activities and behaviors (Tajeddini \& Trueman, 2014; Peng, 2003; Zhou, Yim, \& Tse, 2005; Tajeddini et al., 2017).

As the hotel industry considers the integration of service practices and moves toward sustainable service development, hoteliers should increase their efforts to improve services, processes, designs, and practices moving toward a strategic orientation. This study analyzes strategic orientations in the hotel industry aimed at establishing the potential for progress in terms of service performance and then proposes a suitable strategic orientation for this purpose. The hotel industry is one of the most significant industries in Taiwan, and it is necessary to pay more attention to its development. In the face of increasingly intense competition, service performance improvement is now a critical issue for hoteliers. They must formulate and implement strategies that improve performance and secure a competitive advantage.

Strategic orientations are imprecise and subjective, varying according to the opinions and practical experience of domain experts. The conventional multiple attribute group decisionmaking (MAGDM) models cannot always identify the intricate connections between different hierarchical levels of factors in the subjective hotel industry environment. In addition, MAGDM models usually rely upon the average opinion of experts in the decision-making procedure. However, this approach may be inaccurate when there are large differences in expert opinions. These differences should be considered in the decision-making process because each expert has a different domain-knowledge background. The rough number ap- 
proach is a specialized approach for resolving the subjective and vague judgments of experts during group decision-making. The rough number has a flexible boundary that reflects the vagueness and subjectivity of the judgments (Song et al., 2013). Hence, the objective of this study is to propose a MAGDM with rough number model that can assist experts to make reasonable judgments in a subjective environment.

This model first employs the rough number based decision-making trial and evaluation laboratory (DEMATEL) to construct the evaluating structure. Then, a rough analytic network process (RDANP) approach is applied to obtain a rough influential network relation map (RINRM) and the rough influential weights of the strategic orientations (dimension level) and their corresponding attributes (criteria level). Finally, the modified complex proportional assessment of alternatives with gray relations (mCOPROS-G) method and the criteria weights are used to calculate the relationship ratios for orientations and attributes. The proposed model overcomes the limitations of current decision-making models and can be applied to explore issues that affect real-world service performance. A case study based on the Taiwanese hotel industry is carried out to explore the interdependent issues that affect hotel industry services and to propose alternative strategic orientation procedures that can be employed to achieve optimal service performance.

The main contributions of this approach are threefold. First, selection of strategic orientation is a decision-making problem that must take into account multifaceted interactions and the dependencies encountered in real situations. This study integrates the work of previous studies to provide a method for estimating and improving service performance in the hotel industry. Second, we develop an integrated model that can be employed for making estimations based on the priorities (relative influential weights) of the strategic orientation dimensions/criteria. Our method can handle the complex interdependencies and interactions between dimensions and criteria and produce results that allow the construction of a visual cause-effect diagram to estimate the various strategic processes. In addition, rough numbers represent the various opinions of experts more effectively than has been achieved in prior studies, which have used arithmetic means. Finally, we demonstrate how the outcomes can offer guidance to hoteliers by identifying the key factors for strategy and examining the optimal methods to enhance strategic orientation procedures. The integrated method provides a guide and general strategic orientation estimation framework for hoteliers even if they are not able to completely establish the details of the various strategic orientation models.

This remainder of the study is organized as follows. Section 1 provides a review of the literature on strategic orientations and measurement models. Section 2 proposes a rough MAGDM model. Section 3 demonstrates the proposed techniques in an empirical case study using data from the Taiwanese hotel industry. Section 4 provides some conclusions.

\section{Literature review}

This study first surveys the literature on strategic orientation and its relationships with service performance. We then briefly introduce our proposed strategic orientation measurement model of hotel service performance. 


\subsection{Strategic orientation and service performance}

Strategic orientation has been linked to corporate performance in the hotel industry. Walker and Ruekert (1987) describe strategic orientation as the manner in which an organization decides to compete. It also includes the accomplishment, maintenance, and pursuit of competitive advantage (Varadarajan \& Clark, 1994; Tajeddini, 2011; Tajeddini et al., 2017). According to Ketchen, Thomas, and McDaniel (1996), most normative strategy theories have adopted process (Mintzberg \& Lampel, 1998), content (Veliyath \& Shortell, 1993), or context (Hartman \& Lundberg, 1995) perspectives. Using the classificatory approach, Tajeddini (2011) solved numerous problems and constraints intrinsic to the narrative approach. This approach is seen as a way to investigate and develop novel services in hotels.

Zahay and Handfield (2004) and Srivastava, Shervani, and Fahey (1999) assessed the service value of an organization across three significant categories of service performance: new service development (NSD), customer management (CM), and financial. For instance, more value is created using the NSD procedure in organizations that have greater spanning capability (Day, 1994), and more value is shaped using the CM procedure in organizations that have the capability to classify and nurture long-term relationships and high-value customers. These value abilities improve procedure performance, in turn leading to superior business performance. Here, we use these three categories of performance to analyze the service performance of hotels.

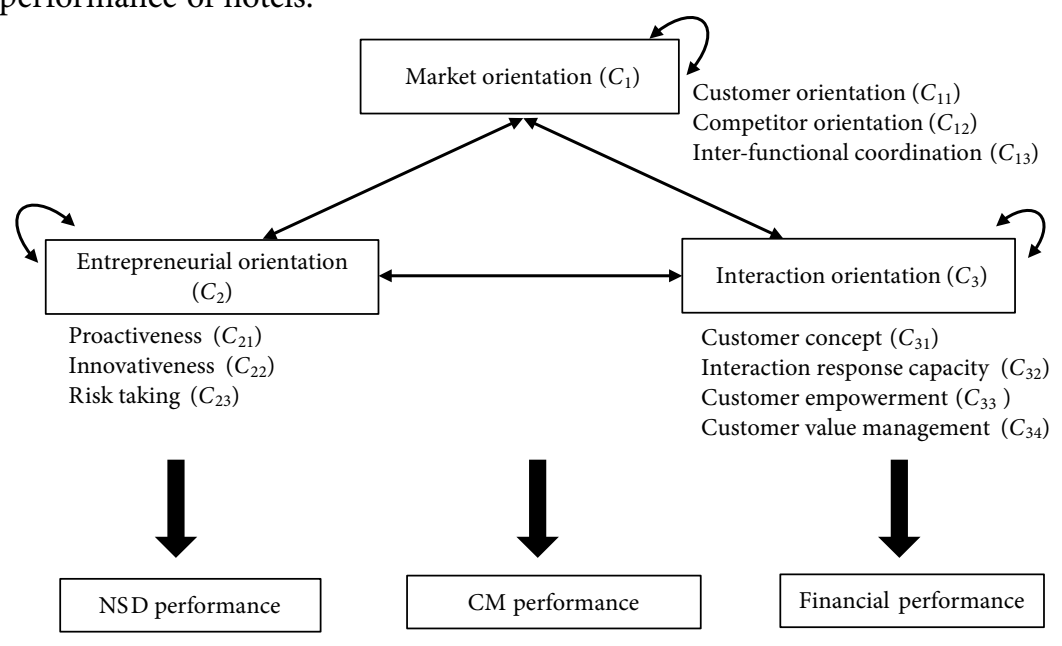

Figure 1. Effect of strategic orientations

The theoretical framework presented in Figure 1 describes the hypothesized relationships between hotel service performance and strategic orientations (NSD, CM, and financial performance).

\subsection{Strategic orientation information}

Researchers have argued the certain categories of strategic orientation make possible improvement in specific types of service performance, however, few have explored which type 
of service performance is most significant for the hotel industry so that hoteliers can make optimal choices. To fill this gap, this study reviews the factors related to market orientation, entrepreneurial orientation, interaction orientation and their relationship to hotel performance.

In terms of corporate culture, market orientation refers to a corporation's disposition to unceasingly provide advantageous value to its consumers ( $\mathrm{Qu} \&$ Zhang, 2015; Slater \& Narver, 1994; Tajeddini, 2010; Tajeddini et al., 2017). This creation of advantageous consumer value requires a business-wide commitment to uninterrupted information gathering about competitor competence and user necessities and the provision of other significant market authorities and agents (Chen, Li, \& Kenneth, 2012; Slater \& Narver, 1995). Narver and Slater (1990) proposed that there are three modules (customer orientation, competitor orientation, and inter-functional coordination) involved in dissemination, intelligence gathering, and responsiveness to collected information. Moreover, they posited that the three principal modules have equal informational value. To summarize, market orientation scholars identify a market-oriented corporate culture as a significant factor behind strong corporate performance. The approach employed herein uses this conceptualization to inspect the structure of market orientation criteria, which comprise customer orientation, competitor orientation, and inter-functional coordination.

Entrepreneurial orientation is a corporation's tendency towards "the pursuit of new market opportunities and the renewal of existing areas of operation" (Hult \& Ketchen, 2001). It promotes a highly proactive approach toward tolerance of risk, market opportunities, and receptiveness to innovation (Matsuno, Mentzer, \& Ozsomer, 2002; Rauch, Wiklund, Lumpkin, \& Frese, 2009; Chen et al., 2012; Kraus, 2013; Tajeddini \& Trueman, 2012; Fernández-Mesa \& Alegre, 2015; X. Jiang, Liu, Fey, \& F. Jiang, 2018). Consequently, the capability to take risks, initiate change, and innovate distinguishes entrepreneurial companies from others (Naman \& Slevin, 1993; Rauch et al., 2009; Chen et al., 2012; Kraus, 2013; Aboelmaged, 2018). An entrepreneurial orientation fosters the spirit needed to create new business opportunities from on-going practices and to revitalize stagnant firms, often through the introduction of breakthrough innovations (Kraus, 2013; Rauch et al., 2009; Chen et al., 2012; Tajeddini, 2010). Hence, the present research assumes this conceptualization to examine the structure of entrepreneurial orientation factors, including innovativeness, proactiveness, and risk-taking.

Interaction orientation refers to an organization's capability to interact with its consumers and apply information attained from them through continuous interaction. The basic notion behind interaction orientation is that customers are considered individuals rather than part of an aggregate. An interaction oriented firm can obtain valuable information which it can use to identify opportunities through useful dialog with customers and then implement active customer empowerment strategies to sustain a competitive advantage (Kumar \& Ramani, 2006; Chen et al., 2012). Some have proposed that interaction orientation is a composite concept consisting of four components: customer concept, interaction response capacity, customer empowerment, and customer value management (Chen et al., 2012; Tung, Liang, \& Chen, 2014; Ramani \& Kumar, 2008; Kumar \& Ramani, 2006). 


\subsection{Strategic orientation measurement model}

From the literature on strategic orientation (Narver \& Slater, 1990; Naman \& Slevin, 1993; Chen et al., 2012; Kumar \& Ramani, 2006; Ramani \& Kumar, 2008; Tung et al., 2014), we obtain 10 criteria and 3 dimensions which influence hotel service performance as outlined in Table 1.

Table 1. Strategic orientation measurement model

\begin{tabular}{|c|c|c|}
\hline Dimensions & Criteria & Descriptions \\
\hline \multirow{3}{*}{$\begin{array}{l}\text { Market } \\
\text { orientation }\left(C_{1}\right)\end{array}$} & Customer orientation $\left(C_{11}\right)$ & $\begin{array}{l}\text { Efficient identification of the target customer to be } \\
\text { able to continuously offer advantages } \\
\text { of importance to them. }\end{array}$ \\
\hline & $\begin{array}{l}\text { Competitor orientation } \\
\left(C_{12}\right)\end{array}$ & $\begin{array}{l}\text { Identification of short-term weaknesses and } \\
\text { strengths and long-term strategies and capabilities } \\
\text { for both significant potential and current } \\
\text { competitors. }\end{array}$ \\
\hline & $\begin{array}{l}\text { Inter-functional } \\
\text { coordination }\left(C_{13}\right)\end{array}$ & $\begin{array}{l}\text { Coordinated utilization of corporation resources } \\
\text { to create advantages important to the target } \\
\text { consumers. }\end{array}$ \\
\hline \multirow{3}{*}{$\begin{array}{l}\text { Entrepreneurial } \\
\text { orientation }\left(C_{2}\right)\end{array}$} & Innovativeness $\left(C_{21}\right)$ & $\begin{array}{l}\text { Degree to which a company engages in } \\
\text { and embraces novelty, ideas, creativity, and } \\
\text { investigation, which can lead to new processes, } \\
\text { services, or products. }\end{array}$ \\
\hline & Risk-taking $\left(C_{22}\right)$ & $\begin{array}{l}\text { Extent to which administrators are willing to take } \\
\text { risks and increase resource commitments. }\end{array}$ \\
\hline & Proactiveness $\left(C_{23}\right)$ & $\begin{array}{l}\text { Extent to which a company acts in expectation } \\
\text { of future market changes and needs. }\end{array}$ \\
\hline \multirow{4}{*}{$\begin{array}{l}\text { Interaction } \\
\text { orientation }\left(C_{3}\right)\end{array}$} & Customer concept $\left(C_{31}\right)$ & $\begin{array}{l}\text { Belief that prescribes the unit of analysis of } \\
\text { each marketing reaction and action toward the } \\
\text { customer. Each customer has unique needs and } \\
\text { cannot be satisfied using one set of offerings. }\end{array}$ \\
\hline & $\begin{array}{l}\text { Interaction response } \\
\text { capacity }\left(C_{32}\right)\end{array}$ & $\begin{array}{l}\text { Degree to which the company quickly responds } \\
\text { to different customers. }\end{array}$ \\
\hline & $\begin{array}{l}\text { Customer empowerment } \\
\left(C_{33}\right)\end{array}$ & $\begin{array}{l}\text { Degree to which the company and the customer } \\
\text { create value during interaction processes. }\end{array}$ \\
\hline & $\begin{array}{l}\text { Customer value } \\
\text { management }\left(C_{34}\right)\end{array}$ & $\begin{array}{l}\text { Degree to which the company can define and } \\
\text { dynamically estimate consumer value and apply } \\
\text { it as a supervisory metric for resource distribution. }\end{array}$ \\
\hline
\end{tabular}

The strategic orientations are subjective and imprecise. They vary according to the opinions and practical experience of domain experts. Rough numbers can effectively express the subjective and vague judgments of experts in the group decision-making process. Thus, we use the rough number method to develop a rough MAGDM model. We examine the relationship between dimensions and criteria using the hybrid MAGDM methods of RDANP and modified COPRAS-G to present models with performance relationship gaps, which are valuable for predicting strategic orientations to enhance NSD, CM, and financial performance. 


\section{Proposed rough MAGDM model}

This study uses the rough number, DANP, and modified COPRAS-G techniques to construct a rough MAGDM model and solve the issues of feedback-effect interrelationships between some criteria or attributes. The model also identifies methods with which to satisfactorily improve the performance relationship gaps for each criterion and dimension. The research process is illustrated in Figure 2.

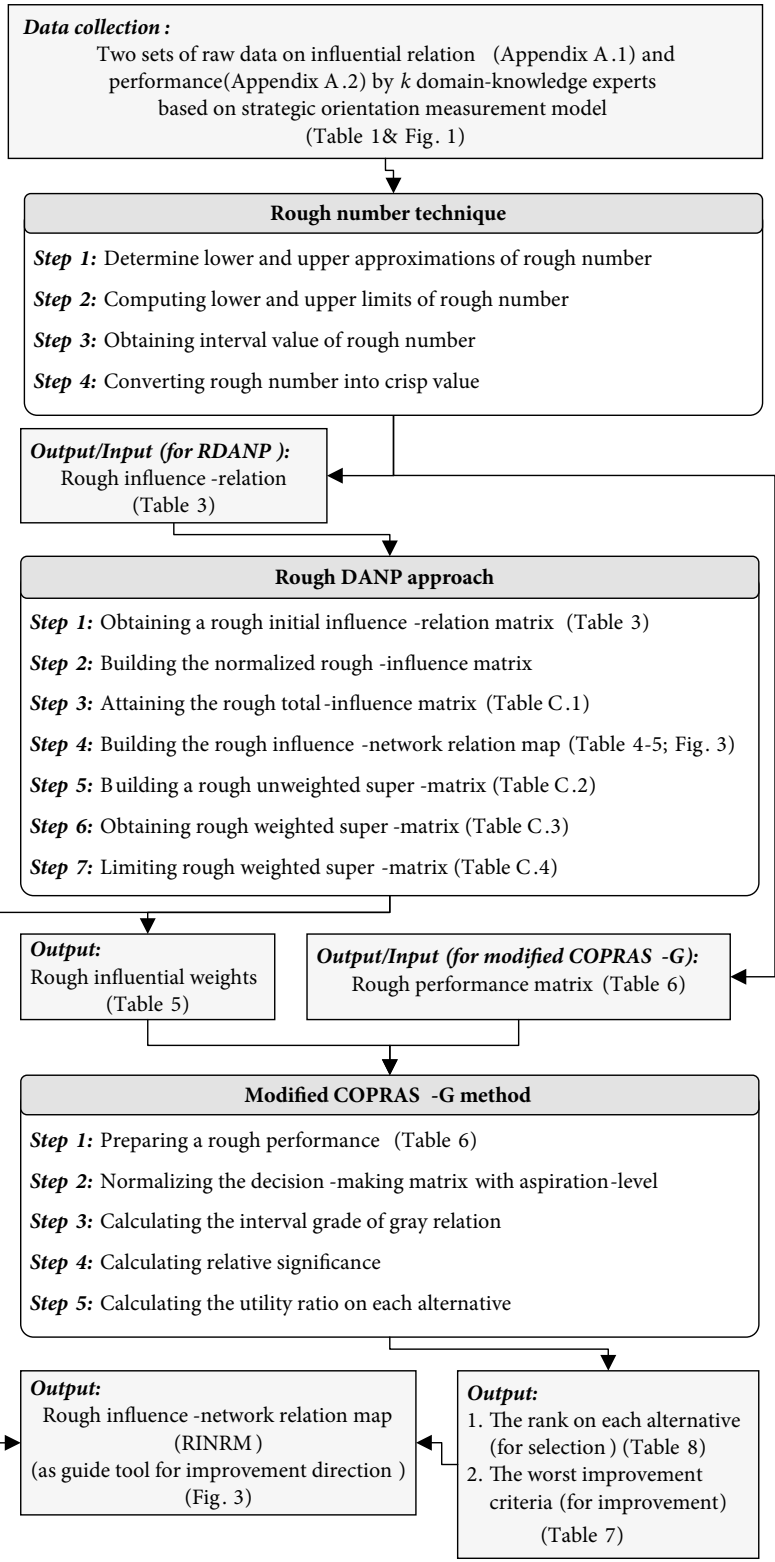

Figure 2. Procedure of the proposed rough MAGDM model 
The rough number technique is used to build an interval value from data obtained from a group of experts. The rough DANP approach is used to build an RINRM and obtain the rough influential weights for each dimension or criterion. The modified COPRAS-G method with rough influential weights is then applied to calculate the performance relationship gaps for the dimensions and criteria. Finally, using the RINRM and performance relationship gaps, we systematically optimize hotel services.

\subsection{Rough numbers}

The concepts and procedures of rough sets were developed by Pawlak (1982) to address subjective and imprecise linguistic variables containing the perceptions and feelings that arise in the real world. Zhai, Khoo, and Zhong (2008) maintains that the theoretical concept can be expanded to determine subjective and imprecise human ideas. They developed the rough number approach to transform a group of crisp numbers into an interval number. The rough number more accurately captures experts' perceptions and does not require any auxiliary information (Zhu, Hu, Qi, Gu, \& Peng, 2015). As a result, the rough number approach has recently been applied to a range of topics such as for sustainable supplier selection (Song et al., 2017b), sustainable supply chain management (Song et al., 2017a), and design concept estimation (Zhu et al., 2015). The detailed mathematical formulations are presented in Appendix B.1.

\subsection{Rough DANP approach}

The DEMATEL technique involves constructing a structural model that addresses complex problems by applying a matrix and related mathematical theories to analyze the effects on and of each factor (Shen, Hu, \& Tzeng, 2017; Lu, Lin, \& Tzeng, 2013; Lu, Tzeng, \& Tang, 2013; Lu, Hu, Huang, \& Tzeng, 2015; Su et al., 2016). The DEMATEL is integrated with the basic concepts of ANP to obtain a set of influential weights for each criterion/dimension. The calculation process employed in the rough DANP approach is derived from the DEMATEL technique and ANP method concepts, but for data processing the rough number technique is used (Chen, Tzeng, \& Huang, 2018; Hu, Jianguo, \& Tzeng, 2018; Lu et al., 2018). The detailed mathematical formulations are presented in Appendix B.2.

\subsection{Modified COPRAS-G method}

The original COPRAS-G concept was derived from real decision-making conditions and gray system theory (Zavadskas, Kaklauskas, Turskis, \& Tamošaitienè, 2008). Deng (1982) developed gray system theory to assess the uncertainty of information or characteristics in white and black systems. Thus, the original COPRAS-G technique identified the optimal result by using the utility degree of alternatives through attribute values expressed as intervals (Hashemkhani Zolfani, Chen, Rezaeiniya, \& Tamošaitienè, 2012). However, in the original COPRAS-G method, the max-min value was adopted as the ideal point; this does not help decision-makers to develop ways in which they can achieve their aspiration levels. Liou, Tamosaitiene, Zavadskas, and Tzeng (2016) therefore modified the COPRAS-G technique by integrating aspirationlevel concepts for evaluating and analyzing the relationship between the utility degree and the aspiration level. The detailed mathematical formulations are presented in Appendix B.3. 


\section{Empirical study}

This section presents an empirical case of the hotel industry of Taiwan to illustrate the effectiveness of the proposed research model.

\subsection{Problem description}

Managers in the hotel industry in Taiwan have faced a lot of challenges, as the industry has experienced constant growth since 2008. In addition to being affected by globalization, which increases the number of competitors, and the improvement of information and communication technologies, which enable consumers to compare offerings (Koch \& Cebula, 2002; Rowley, 2004; Tajeddini \& Trueman, 2014; Tajeddini et al., 2017), the hotel industry is vulnerable to various political, financial, and public health crises (OCDE, 2003), as well as economic booms and government changes. It must also meet constantly evolving consumer service quality expectations (Skogland \& Siguaw, 2004) and respond to consumers' increasing social awareness (Jiang \& Kim, 2015; Miller, 2003).

We therefore propose a rough MAGDM model that estimates the degree of criterion preference to determine the weights of influence of various criteria and identify the most critical impact criteria in the strategic orientation process. An empirical study is employed to illustrate the application of the proposed hybrid rough MAGDM model for estimating and selecting the optimal enhancement method. The model will also help decision makers to realize how to enhance their evaluation of strategic orientation, with the objective of achieving the aspired to service performance in relation to the different criteria and dimensions.

\subsection{Data collection}

The scholars and experts consulted in this study have been involved in hotel and tourism related research in Taiwan for many years. For this study, we recruited two scholars of the hotel industry, seven hotel proprietors, and one government official in charge of tourism to complete a questionnaire. First, from the perspective of the strategic orientation measurement model (Table 1), the experts were asked to assess the influences of the criteria on a

Table 2. Significant confidence obtained using 10-fold cross-validation

\begin{tabular}{|l|c|c|c|c|c|c|c|}
\hline Number of expert & No.1 & No.2 & No.3 & No.4 & No.5 & \multicolumn{2}{|c|}{ Average } \\
\hline Gap & 0.022 & 0.038 & 0.044 & 0.016 & 0.032 & & \\
\cline { 1 - 6 } Gap (\%) & $2.2 \%$ & $3.8 \%$ & $4.4 \%$ & $1.6 \%$ & $3.2 \%$ & \multirow{2}{*}{ Gap } & 0.028 \\
\cline { 1 - 5 } Number of expert & No.6 & No.7 & No.8 & No.9 & No.10 & & \\
\cline { 1 - 6 } Gap & 0.026 & 0.020 & 0.029 & 0.027 & 0.027 & \multirow{2}{*}{ Gap (\%) } & \multirow{2}{*}{$2.81 \%$} \\
\cline { 1 - 6 } Gap (\%) & $2.6 \%$ & $2.0 \%$ & $2.9 \%$ & $2.7 \%$ & $2.7 \%$ & & \\
\hline
\end{tabular}

Note: The significant confidence is formulated as follows:

$\frac{1}{n(n-1)} \sum_{i=1}^{n} \sum_{j=1}^{n} \frac{\left|d_{i j}^{k}-d_{i j}^{k-1}\right|}{d_{i j}^{k}} \times 100 \%=2.81 \%<5 \%$; the significant confidence is thus $97.19 \% ; k=10$ denotes the number of experts; $d_{i j}^{k}$ is the average influence degree of criterion $i$ on criterion $j$; and $n$ denotes the number of criteria, here $n=10$. 
5-point Likert scale ranging from no influence (0) to very strong influence (4). The consensus rate of significant confidence was $97.19 \%$, which exceeds the $95 \%$ confidence level (i.e., gap error rate $=2.81 \%$; less than $5 \%$ ) (Table 2 in footnote).

\subsection{Constructing the RINRM and rough weights using the rough DANP approach}

All of the criteria that were found to influence the data are provided (in verbal scales) in Table A.1 (in Appendix A). Although there may be good consensus in the overall collected data, using the average values to represent the experts' opinions from the pairwise survey is not reasonable. Therefore, we applied rough numbers to represent the various estimations. For example, the evaluation set for customer orientation $\left(C_{12}\right)$ on competitor orientation $\left(C_{11}\right)$ can be denoted $C_{12}-C_{11}=\{3,2,1,3,3,3,4,4,3,3\}$. To manipulate the subjective, imprecise, and vague linguistic decision-making information in the influence relationship of the strategic orientations, $C_{12}-C_{11}$ is converted into a rough interval according to Eqs (B1)-(B4) as follows:

$$
\begin{aligned}
& \underline{\operatorname{Lim}}(1)=\frac{1}{1}=1, \overline{\operatorname{Lim}}(1)=\frac{1+2+3+3+3+3+3+3+4+4}{10}=2.9 ; \\
& \underline{\operatorname{Lim}}(2)=\frac{1+2}{2}=1.5, \overline{\operatorname{Lim}}(2)=\frac{2+3+3+3+3+3+3+4+4}{9}=3.11 ; \\
& \underline{\operatorname{Lim}}(3)=\frac{1+2+3+3+3+3+3+3}{8}=2.625, \overline{\operatorname{Lim}}(3)=\frac{3+3+3+3+3+3+4+4}{8}=3.25 ; \\
& \underline{\operatorname{Lim}}(4)=\frac{1+2+3+3+3+3+3+3+4+4}{10}=2.9, \overline{\operatorname{Lim}}(4)=\frac{4+4}{2}=4 .
\end{aligned}
$$

$C_{12}-C_{11}$ can then be converted into a rough interval set as follows: $C_{12}-C_{11}=\{[2.62,3.25]$, $[1.5,3.11],[1,2.9],[2.62,3.25],[2.62,3.25],[2.62,3.25],[2.9,4],[2.9,4],[2.62,3.25],[2.62$, 3.25]\}. The rough interval value of $C_{12}-C_{11}$ (i.e., $a_{12}$ ) is as follows:

$$
\begin{aligned}
R N\left(a_{12}\right) & =\left[\begin{array}{ll}
2.41, & 3.35
\end{array}\right] \\
& =\left[\begin{array}{l}
\frac{2.625+1.5+1+2.625+2.625+2.625+2.9+2.92 .625+2.625}{10} \\
\frac{3.25+3.11+2.9+3.25+3.25+3.25+4+4+3.25+3.25}{10}
\end{array}\right] .
\end{aligned}
$$

The other rough interval values of elements in the rough initial direct-relationship matrix $\tilde{\boldsymbol{A}}$ can be attained in a similar way. The rough initial direct-relationship matrix $\tilde{\boldsymbol{A}}$ obtained is shown in in Table 3.

The rough initial direct-relationship matrix $\tilde{\boldsymbol{A}}$ was used in Eqs (B9) and (B10) to obtain the normalized rough-influence-relationship matrix $\tilde{\boldsymbol{D}}$. Then, Eq. (B11) was used to derive the rough total-influence matrix $\tilde{T}_{c}$ (Table C.1 in Appendix C). The total-influence matrix $\tilde{\boldsymbol{T}}_{D}$ for the dimensions was obtained by averaging the rough total-influence $\tilde{T}_{c}$ within the corresponding dimensions. Equation (B13) can be employed using these rough total-influence matrixes of criteria $\tilde{T}_{c}$ and dimensions $\tilde{\boldsymbol{T}}_{D}$ to obtain the rough influence given $(\tilde{\boldsymbol{P}})$ and rough influence received $(\tilde{\boldsymbol{q}})$ for each criterion and dimension (Table 4 ). 
Table 3. Significant confidence obtained using 10 -fold cross-validation

\begin{tabular}{|c|c|c|c|c|c|c|c|c|c|c|}
\hline$\tilde{\boldsymbol{A}}$ & $C_{11}$ & $C_{12}$ & $C_{13}$ & $C_{21}$ & $C_{22}$ & $C_{23}$ & $C_{31}$ & $C_{32}$ & $C_{33}$ & $C_{34}$ \\
\hline$C_{11}$ & - & {$[2.28,3.48]$} & {$[2.59,3.60]$} & {$[3.13,3.85]$} & {$[2.49,3.64]$} & {$[2.22,3.56]$} & {$[3.64,3.96]$} & {$[3.49,3.91]$} & {$[3.36,3.84]$} & {$[3.25,3.75]$} \\
\hline$C_{12}$ & {$[2.41,3.35]$} & - & {$[2.15,3.43]$} & {$[3.25,3.75]$} & {$[2.59,3.60]$} & {$[3.02,3.76]$} & {$[2.16,3.16]$} & {$[1.38,2.95]$} & {$[1.68,2.84]$} & {$[1.65,3.07]$} \\
\hline$C_{13}$ & {$[2.02,3.19]$} & {$[2.24,2.98]$} & - & {$[1.47,2.89]$} & {$[1.52,2.73]$} & {$[1.59,3.05]$} & {$[1.65,2.35]$} & {$[1.73,2.89]$} & {$[1.28,2.48]$} & {$[1.11,2.53]$} \\
\hline$C_{21}$ & {$[2.57,3.75]$} & {$[2.69,3.51]$} & {$[1.29,2.93]$} & - & {$[2.94,3.65]$} & {$[2.75,3.64]$} & {$[3.16,3.64]$} & {$[2.33,3.62]$} & {$[2.28,3.47]$} & {$[2.42,3.35]$} \\
\hline$C_{22}$ & {$[2.08,2.89]$} & {$[2.12,3.27]$} & {$[1.83,2.75]$} & {$[2.28,3.48]$} & - & {$[2.44,3.51]$} & {$[2.02,3.32]$} & {$[1.71,3.41]$} & {$[1.40,3.16]$} & {$[1.19,2.81]$} \\
\hline$C_{23}$ & {$[2.87,3.52]$} & {$[3.16,3.64]$} & {$[2.11,3.08]$} & {$[3.25,3.92]$} & {$[2.83,3.75]$} & - & {$[2.16,3.34]$} & {$[1.87,3.60]$} & {$[1.55,2.80]$} & {$[1.92,3.06]$} \\
\hline$C_{31}$ & {$[3.64,3.96]$} & {$[2.36,3.25]$} & {$[2.35,3.06]$} & {$[2.94,3.65]$} & {$[2.25,2.92]$} & {$[2.26,3.31]$} & - & {$[2.87,3.52]$} & {$[2.49,3.64]$} & {$[3.02,3.76]$} \\
\hline$C_{32}$ & {$[3.13,3.85]$} & {$[1.87,3.07]$} & {$[1.92,2.89]$} & {$[2.12,2.89]$} & {$[1.81,2.99]$} & {$[2.75,3.64]$} & {$[3.13,3.85]$} & - & {$[2.71,3.64]$} & {$[2.59,3.60]$} \\
\hline$C_{33}$ & {$[3.25,3.92]$} & {$[2.06,3.11]$} & {$[1.83,2.75]$} & {$[2.36,2.75]$} & {$[1.42,2.76]$} & {$[2.49,3.31]$} & {$[3.36,3.84]$} & {$[2.94,3.65]$} & - & {$[2.42,3.72]$} \\
\hline$C_{34}$ & {$[3.25,3.92]$} & {$[2.13,2.85]$} & {$[1.41,2.35]$} & {$[2.41,2.35]$} & {$[2.24,3.13]$} & {$[2.65,3.35]$} & {$[2.28,3.48]$} & {$[2.65,3.35]$} & {$[2.02,3.54]$} & - \\
\hline
\end{tabular}

Table 4. Rough influences given and received for each criterion and dimension

\begin{tabular}{|c|c|c|c|c|c|c|c|c|c|}
\hline & $\begin{array}{l}\text { Influences } \\
\text { given }\end{array}$ & $\begin{array}{c}\text { Influences } \\
\text { received }\end{array}$ & $\begin{array}{l}\text { Promi- } \\
\text { nence }\end{array}$ & $\begin{array}{c}\text { Net cause/ } \\
\text { effect }\end{array}$ & & $\begin{array}{c}\text { Influences } \\
\text { given }\end{array}$ & $\begin{array}{c}\text { Influences } \\
\text { received }\end{array}$ & $\begin{array}{l}\text { Promi- } \\
\text { nence }\end{array}$ & $\begin{array}{c}\text { Net cause/ } \\
\text { effect }\end{array}$ \\
\hline \multirow{3}{*}{$C_{1}$} & \multirow{3}{*}[0.5,2.59]{} & \multirow{3}{*}[0.52,2.59]{} & \multirow{3}{*}[1.02,5.18]{} & \multirow{3}{*}[-2.08,2.07]{} & $C_{11}$ & {$[2.14,9.73]$} & {$[2.04,9.41]$} & {$[4.19,19.15]$} & {$[-7.27,7.69]$} \\
\hline & & & & & $C_{12}$ & {$[1.66,8.75]$} & {$[1.71,8.57]$} & {$[3.38,17.31]$} & {$[-6.91,7.03]$} \\
\hline & & & & & $C_{13}$ & {$[1.22,7.46]$} & {$[1.45,7.94]$} & {$[2.67,15.40]$} & {$[-6.72,6.01]$} \\
\hline \multirow{3}{*}{$C_{2}$} & \multirow{3}{*}[0.5,2.66]{} & \multirow{3}{*}[0.53,2.68]{} & \multirow{3}{*}[1.04,5.34]{} & \multirow{3}{*}[-2.17,2.12]{} & $C_{21}$ & {$[1.84,9.21]$} & {$[1.90,9.17]$} & {$[3.74,18.39]$} & {$[-7.33,7.31]$} \\
\hline & & & & & $C_{22}$ & {$[1.41,8.42]$} & {$[1.66,8.58]$} & {$[3.08,16.99]$} & {$[-7.16,6.76]$} \\
\hline & & & & & $C_{23}$ & {$[1.77,8.98]$} & {$[1.81,9.09]$} & {$[3.58,18.06]$} & {$[-7.31,7.17]$} \\
\hline \multirow{4}{*}{$C_{3}$} & \multirow{4}{*}[0.56,2.68]{} & \multirow{4}{*}[0.51,2.66]{} & \multirow{4}{*}[1.07,5.34]{} & \multirow{4}{*}[-2.10,2.17]{} & $C_{31}$ & {$[1.98,9.10]$} & {$[1.93,9.06]$} & {$[3.90,18.16]$} & {$[-7.09,7.17]$} \\
\hline & & & & & $C_{32}$ & {$[1.82,9.03]$} & {$[1.73,9.04]$} & {$[3.55,18.06]$} & {$[-7.22,7.30]$} \\
\hline & & & & & $C_{33}$ & {$[1.84,8.90]$} & {$[1.57,8.65]$} & {$[3.41,17.56]$} & {$[-6.81,7.34]$} \\
\hline & & & & & $C_{34}$ & {$[1.74,8.65]$} & {$[1.63,8.71]$} & {$[3.37,17.36]$} & {$[-6.97,7.02]$} \\
\hline
\end{tabular}

From the deroughness results obtained in this investigation (Table 5), we discover that "interaction orientation $\left(C_{3}\right)$ " has the strongest total influence and is the most influential dimension. The dimension "market orientation $\left(C_{1}\right)$ " has the weakest effects on the other dimensions. From the net cause-effect influential relationship $(\boldsymbol{p}-\boldsymbol{q})$, "interaction orientation $\left(C_{3}\right)$ " is identified as having the strongest effect on the other dimensions.

Figure 3 further illustrates this effect. The influence priority can be sequenced as interaction orientation $\left(C_{3}\right) \succ$ market orientation $\left(C_{1}\right) \succ$ entrepreneurial orientation $\left(C_{2}\right)$. When considering how to enhance service performance, the hotel administration experts all considered the interaction orientation $\left(C_{3}\right)$ to be the most effective because it affects the market orientation $\left(C_{1}\right)$ and the entrepreneurial orientation $\left(C_{2}\right)$. 
Table 5. Deroughness influences given and received for each criterion and dimension

\begin{tabular}{|c|c|c|c|c|c|c|c|c|c|}
\hline & $\begin{array}{c}\text { Influences } \\
\text { given }\end{array}$ & $\begin{array}{c}\text { Influences } \\
\text { received }\end{array}$ & Prominence & $\begin{array}{c}\text { Net cause/ } \\
\text { effect }\end{array}$ & & $\begin{array}{l}\text { influences } \\
\text { given }\end{array}$ & $\begin{array}{c}\text { influences } \\
\text { received }\end{array}$ & Prominence & $\begin{array}{c}\text { Net cause/ } \\
\text { effect }\end{array}$ \\
\hline \multirow{3}{*}{$C_{1}$} & \multirow{3}{*}{1.55} & \multirow{3}{*}{1.55} & \multirow{3}{*}{$3.10(3)$} & \multirow{3}{*}{$0.00(2)$} & $C_{11}$ & 5.94 & 5.73 & $11.67(1)$ & $0.21(1)$ \\
\hline & & & & & $C_{12}$ & 5.20 & 5.14 & $10.34(2)$ & $0.06(2)$ \\
\hline & & & & & $C_{13}$ & 4.34 & 4.69 & $9.03(3)$ & $-0.36(3)$ \\
\hline \multirow{3}{*}{$C_{2}$} & \multirow{3}{*}{1.58} & \multirow{3}{*}{1.61} & \multirow{3}{*}{$3.19(2)$} & \multirow{3}{*}{$-0.03(3)$} & $C_{21}$ & 5.53 & 5.54 & $11.07(1)$ & $-0.01(1)$ \\
\hline & & & & & $C_{22}$ & 4.92 & 5.12 & $10.04(3)$ & $-0.20(3)$ \\
\hline & & & & & $C_{23}$ & 5.38 & 5.45 & $10.82(2)$ & $-0.07(2)$ \\
\hline \multirow{4}{*}{$C_{3}$} & \multirow{4}{*}{1.62} & \multirow{4}{*}{1.59} & \multirow{4}{*}{$3.20(1)$} & \multirow{4}{*}{$0.03(1)$} & $C_{31}$ & 5.54 & 5.50 & $11.03(1)$ & $0.04(2)$ \\
\hline & & & & & $C_{32}$ & 5.42 & 5.38 & $10.81(2)$ & $0.04(3)$ \\
\hline & & & & & $C_{33}$ & 5.37 & 5.11 & $10.48(3)$ & $0.26(1)$ \\
\hline & & & & & $C_{34}$ & 5.20 & 5.17 & $10.37(4)$ & $0.03(4)$ \\
\hline
\end{tabular}

Note: ( ) is ranking on the local area.

In the market orientation dimension, customer orientation $\left(C_{11}\right)$ directly affects competitor orientation $\left(C_{12}\right)$ and inter-functional coordination $\left(C_{13}\right)$, indicating that the priority for improvement should be $\left(C_{11}\right) \succ\left(C_{12}\right) \succ\left(C_{13}\right)$. In the entrepreneurial orientation $\left(C_{2}\right)$ dimension, innovativeness $\left(C_{21}\right)$ directly affects proactiveness $\left(C_{23}\right)$ and risk taking $\left(C_{22}\right)$, indicating that the improvement priority should be $\left(C_{21}\right) \succ\left(C_{23}\right) \succ\left(C_{22}\right)$. Similarly, the improvement priority should be $\left(C_{33}\right) \succ\left(C_{32}\right) \succ\left(C_{31}\right) \succ\left(C_{34}\right)$ in the interaction orientation $\left(C_{3}\right)$. For decision makers looking for solutions in a complex system with a variety dimensions and criteria, the derived RINRM illustrated in Figure 3 provides a clear picture and simplifies the identification of priorities for enhancement within the complex system. Hence, administrators should estimate all of the criteria and dimensions for these strategic orientations for service performance as in Figure 3. This estimation method is applicable in most cases in the hotel industry in the real world. However, administrators should bear in mind that, when using this model, some variance will exist between strategies.

After constructing the RINRM, we applied rough DANP to obtain the rough influential weights of the criteria. The total-influence matrix of criteria $\tilde{T}_{c}$ (Table C.1 in Appendix C) was used to construct a rough unweighted supermatrix using Eq. (B14) (Table C.2 in Appendix C). Considering the different degrees of rough influence between dimensions, we employed Eqs. (B15)-(B17) to calculate the rough weighted supermatrix $\tilde{\boldsymbol{W}}^{\phi}$ (Table C.3 in Appendix C). Based on the concepts of the Markov chain and ANP, the limits of the rough weighted supermatrix $\tilde{\boldsymbol{W}}^{\phi}$ were calculated by raising it to limited powers until the rough weighted supermatrix was converged (Table C.4 in Appendix C).

From the obtained limits of the rough weighted matrix (Table C.4 in Appendix C), we derived the local and global rough weights for the dimensions and criteria (Table 6). The rough DANP approach enabled us to derive the local rough weights of the assessment attributes at their respective hierarchical levels and to derive the global rough weights, permitting understanding of the absolute weight of individual criteria from the overall perspectives. Entrepreneurial orientation $\left(C_{2}\right)$ was discovered to have the highest weight among the dimensions, and to be the most critical criterion in the market, entrepreneurial, and interaction dimensions was customer orientation $\left(C_{11}\right)$, innovativeness $\left(C_{21}\right)$, and customer concepts $\left(C_{31}\right)$, respectively. 


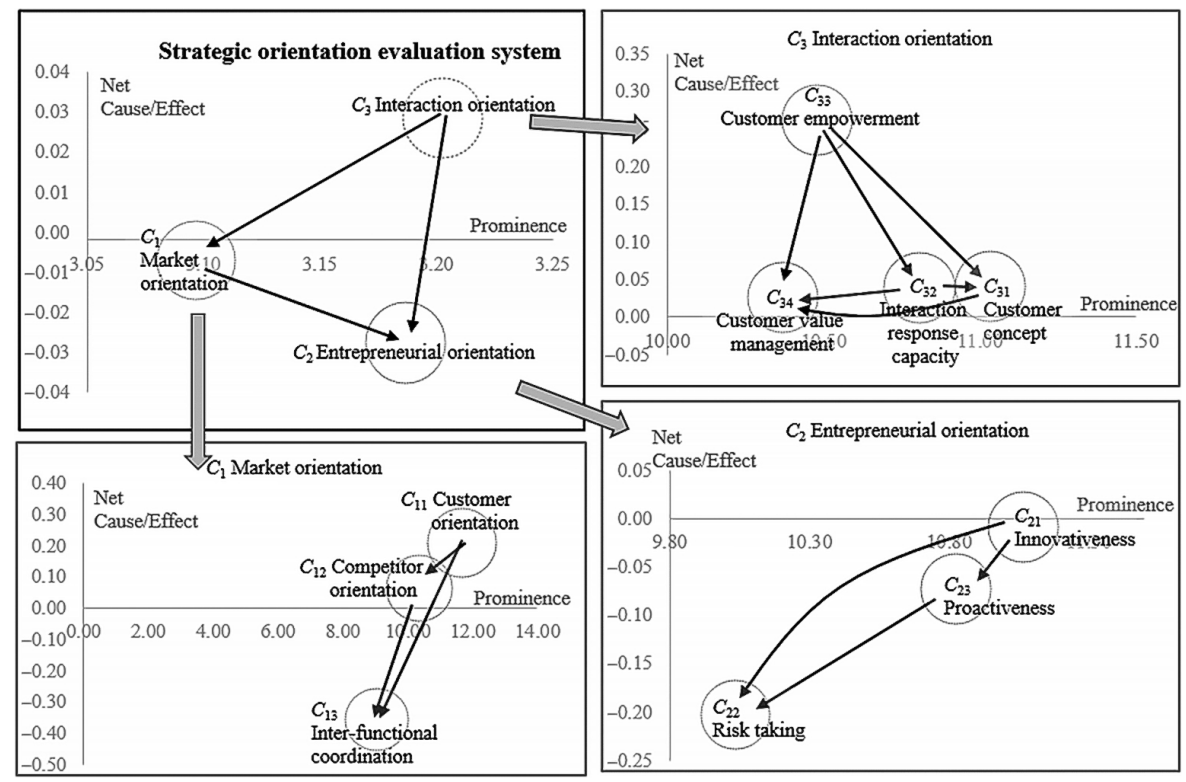

Figure 3. Procedure of our proposed rough MAGDM model

Table 6. Rough influence weights for each dimension and criterion

\begin{tabular}{|c|c|c|c|c|c|c|c|c|c|c|}
\hline & $\begin{array}{l}\text { Local } \\
\text { weigh }\end{array}$ & $\begin{array}{c}\text { De- } \\
\text { roughness }\end{array}$ & Rank & & Local weigh & $\begin{array}{c}\text { De- } \\
\text { roughness }\end{array}$ & Rank & Global weigh & $\begin{array}{c}\text { De- } \\
\text { roughness }\end{array}$ & Rank \\
\hline \multirow{3}{*}{$C_{1}$} & \multirow{3}{*}{$\begin{array}{l}{[0.065,} \\
0.326]\end{array}$} & \multirow{3}{*}{0.196} & \multirow{3}{*}{3} & $C_{11}$ & {$[0.389,0.363]$} & 0.376 & 1 & {$[0.025,0.118]$} & 0.072 & 1 \\
\hline & & & & $C_{12}$ & {$[0.332,0.331]$} & 0.331 & 2 & {$[0.022,0.108]$} & 0.065 & 4 \\
\hline & & & & $C_{13}$ & {$[0.279,0.306]$} & 0.293 & 3 & {$[0.018,0.100]$} & 0.059 & 6 \\
\hline \multirow{3}{*}{$C_{2}$} & \multirow{3}{*}{$\begin{array}{l}{[0.067,} \\
0.338]\end{array}$} & \multirow{3}{*}{0.203} & \multirow{3}{*}{1} & $C_{21}$ & {$[0.354,0.342]$} & 0.348 & 1 & {$[0.024,0.116]$} & 0.070 & 2 \\
\hline & & & & $C_{22}$ & {$[0.310,0.320]$} & 0.315 & 3 & {$[0.021,0.108]$} & 0.064 & 5 \\
\hline & & & & $C_{23}$ & {$[0.336,0.339]$} & 0.337 & 2 & {$[0.023,0.114]$} & 0.069 & 3 \\
\hline \multirow{4}{*}{$C_{3}$} & \multirow{4}{*}{$\begin{array}{l}{[0.065,} \\
0.336]\end{array}$} & \multirow{4}{*}{0.200} & \multirow{4}{*}{2} & $C_{31}$ & {$[0.281,0.256]$} & 0.269 & 1 & {$[0.018,0.086]$} & 0.052 & 7 \\
\hline & & & & $C_{32}$ & {$[0.252,0.255]$} & 0.254 & 2 & {$[0.016,0.086]$} & 0.051 & 8 \\
\hline & & & & $C_{33}$ & {$[0.229,0.244]$} & 0.237 & 4 & {$[0.015,0.082]$} & 0.048 & 10 \\
\hline & & & & $C_{34}$ & {$[0.237,0.246]$} & 0.241 & 3 & {$[0.015,0.082]$} & 0.049 & 9 \\
\hline
\end{tabular}

\subsection{Evaluating the rough relative-utility ratios using the modified COPRAS-G method}

This section explains how we assessed the rough relative-utility degrees between current strategic orientation performance and aspiration level for the 10 criteria. First, the performance values of each criterion were investigated by collecting the 10 experts' performance levels for each criterion (Table A.2 in Appendix A). The NSD, CM, and financial performance values were then used to determine the rough evaluation scores, which were expressed as an interval (Table 7). Then, combining the rough influential weights and following the steps of COPRAS$\mathrm{G}$, we obtained the relative significance of each criterion, the grey grade of the lower and upper bounds, the degree of utility, and the final ranking of each strategy (Tables 8 and 9). 
As shown in Table 9, CM performance has a utility degree of $68.42 \%$ so is selected as the most suitable strategy; NSD performance has a utility degree of $66.33 \%$ and is the second priority; and financial performance has a utility degree of $60.11 \%$ and is the lowest priority. Although the CM performance strategy has the highest priority, it only achieves a rough utility degree of $68.42 \%$ of the aspiration level. In other words, CM performance has a gap of $31.38 \%$ that must be addressed.

Table 7. Rough evaluation scores of alternatives with aspiration levels

\begin{tabular}{|l|c|c|c|c|c|}
\hline \multicolumn{1}{|c|}{ Criteria } & Global weight & $\begin{array}{c}\text { Aspiration- } \\
\text { level }\end{array}$ & $\begin{array}{c}\text { NSD } \\
\text { performance }\end{array}$ & $\begin{array}{c}\text { CM } \\
\text { performance }\end{array}$ & $\begin{array}{c}\text { Financial } \\
\text { performance }\end{array}$ \\
\hline Customer orientation $\left(C_{11}\right)$ & {$[0.025,0.118]$} & {$[10,10]$} & {$[5.36,7.97]$} & {$[8.15,9.43]$} & {$[5.73,6.89]$} \\
\hline Competitor orientation $\left(C_{12}\right)$ & {$[0.022,0.108]$} & {$[10,10]$} & {$[5.39,6.96]$} & {$[4.63,7.04]$} & {$[4.55,7.13]$} \\
\hline Inter-functional coordination $\left(C_{13}\right)$ & {$[0.018,0.100]$} & {$[10,10]$} & {$[4.69,6.67]$} & {$[4.57,6.77]$} & {$[5.23,6.96]$} \\
\hline Innovativeness $\left(C_{21}\right)$ & {$[0.024,0.116]$} & {$[10,10]$} & {$[8.02,9.19]$} & {$[6.24,7.58]$} & {$[5.15,6.43]$} \\
\hline Risk taking $\left(C_{22}\right)$ & {$[0.021,0.108]$} & {$[10,10]$} & {$[6.48,8.14]$} & {$[5.81,6.99]$} & {$[3.45,6.83]$} \\
\hline Proactiveness $\left(C_{23}\right)$ & {$[0.023,0.114]$} & {$[10,10]$} & {$[5.94,7.82]$} & {$[5.72,7.61]$} & {$[4.15,7.60]$} \\
\hline Customer concepts $\left(C_{31}\right)$ & {$[0.018,0.086]$} & {$[10,10]$} & {$[5.88,7.90]$} & {$[6.99,8.31]$} & {$[4.14,6.58]$} \\
\hline Interaction response capacity $\left(C_{32}\right)$ & {$[0.016,0.086]$} & {$[10,10]$} & {$[6.01,7.46]$} & {$[7.22,8.56]$} & {$[4.57,7.04]$} \\
\hline Customer empowerment $\left(C_{33}\right)$ & {$[0.015,0.082]$} & {$[10,10]$} & {$[4.84,6.85]$} & {$[6.64,8.20]$} & {$[3.82,6.53]$} \\
\hline Customer value management $\left(C_{10}\right)$ & {$[0.015,0.082]$} & {$[10,10]$} & {$[3.44,6.68]$} & {$[5.16,7.84]$} & {$[4.44,7.79]$} \\
\hline
\end{tabular}

Table 8. Relative significance of each criterion

\begin{tabular}{|l|c|c|c|}
\hline \multicolumn{1}{|c|}{ Criteria } & NSD performance & CM performance & Financial performance \\
\hline Customer orientation $\left(C_{11}\right)$ & 0.049 & 0.062 & 0.043 \\
\hline Competitor orientation $\left(C_{12}\right)$ & 0.039 & 0.039 & 0.039 \\
\hline Inter-functional coordination $\left(C_{13}\right)$ & 0.034 & 0.035 & 0.036 \\
\hline Innovativeness $\left(C_{21}\right)$ & 0.058 & 0.046 & 0.040 \\
\hline Risk taking $\left(C_{22}\right)$ & 0.045 & 0.039 & 0.038 \\
\hline Proactiveness $\left(C_{23}\right)$ & 0.046 & 0.045 & 0.044 \\
\hline Customer concepts $\left(C_{31}\right)$ & 0.035 & 0.038 & 0.030 \\
\hline Interaction response capacity $\left(C_{32}\right)$ & 0.033 & 0.038 & 0.031 \\
\hline Customer empowerment $\left(C_{33}\right)$ & 0.029 & 0.035 & 0.027 \\
\hline Customer value management $\left(C_{10}\right)$ & 0.028 & 0.033 & 0.032 \\
\hline
\end{tabular}

Table 9. Rough evaluation of the utility degree of each alternative

\begin{tabular}{|l|c|c|c|c|c|}
\hline \multicolumn{1}{|c|}{ Alternatives } & $\begin{array}{c}\text { Interval grade of gray } \\
\text { relation }\end{array}$ & $\begin{array}{c}\text { Relative } \\
\text { significance }\end{array}$ & Utility degree & Gaps & $\begin{array}{c}\text { Improvement } \\
\text { rank }\end{array}$ \\
\hline $\begin{array}{l}\text { NSD } \\
\text { performance }\end{array}$ & {$[0.11,0.69]$} & 0.40 & $66.33 \%$ & $33.67 \%$ & 2 \\
\hline CM performance & {$[0.11,0.71]$} & 0.41 & $68.42 \%$ & $31.58 \%$ & 3 \\
\hline $\begin{array}{l}\text { Financial } \\
\text { performance }\end{array}$ & {$[0.09,0.62]$} & 0.36 & $60.11 \%$ & $39.89 \%$ & 1 \\
\hline
\end{tabular}




\subsection{Discussion and implications}

We examined an empirical example of hotel service performance enhancement in Taiwan. We first explored the network relationship between dimensions and criteria by employing the RINRM (Figure 3). As can be seen in Figure 3, the priorities for enhancement were sequenced as follows: interaction orientation $\succ$ market orientation $\succ$ entrepreneurial orientation. For hoteliers, this sequence is a vital finding because it shows which strategic issues should be addressed first. Efforts in this direction will produce network effects on the remaining dimensions and simultaneously resolve multiple problems. The RINRM presented herein illustrates the influential networks containing nonlinear relationships, for both dimensions and criteria. We consider that this interaction orientation reflects a hotel's capability to interact with its consumers and to take advantage of information obtained from them through consecutive interactions to realize beneficial consumer relations.

Second, the criteria of customer orientation $\left(C_{11}\right)$, innovativeness $\left(C_{21}\right)$, and customer empowerment $\left(C_{33}\right)$, influence the other criteria in their individual dimension, as illustrated in Figure 3. Notably, customer orientation $\left(C_{11}\right)$ is critical to successful programs, enabling firms to constantly improve their offerings to customers, which is consistent with the conclusions reported by Lukas and Maignan (1996). Customer orientation benefits new service or product development, helps to increase perceived service or product quality, and ultimately increases customer loyalty in the hotel industry. Innovativeness $\left(C_{21}\right)$ also deserves further attention. A more innovative organization is willing to invest a high percentage of resources in projects with uncertain outcomes and is willing to enter unfamiliar markets. Innovativeness reflects an organization's predisposition to embrace new ideas, novelty, experimentation, and creativity (Wang, 2008). For instance, the core management philosophy in Taiwan's hotel industry has mainly focused on service quality and partial enhancements rather than innovation. Since the beginning of rapidly changes to the environment and the increased service requests, Taiwan's hotels have striven to develop core competencies. The industry has used domestic innovation capabilities as a yardstick for the evaluation of successful performance, combined with cultural and creative activities and the characteristics of the local environment. Furthermore, customer empowerment $\left(C_{33}\right)$ reflects the extent to which an organization provides avenues through which its customers can connect with the organization and actively collaborate and shape the nature of transactions. It also involves sharing praise, criticism, information, ideas, and suggestions about the organization's policies, products, and services (Ramani \& Kumar, 2008; Chen et al., 2012; Tung et al., 2014; Tajeddini et al., 2017; García-Villaverde, Elche, \& Martínez-Pérez, 2017).

Third, the most important criterion as calculated by the RDANP was customer orientation, with a weight of 0.072 (Table 6). Hoteliers should implement customer oriented services and attract more customers. Customer orientation is therefore the most significant criterion when evaluating strategic orientation to enhance service performance in the hotel industry (Tajeddini \& Trueman, 2014). Based on this result, the consumer is the most significant external element in the surroundings. Enhancing business and market orientation requires improvement in customer related strategy. In addition, the significance of the role of the members of front line staff should not be disregarded. The services and the service 
provider are frequently seen as synonymous in the eyes of the customer. On the other hand, the employee's level of customer orientation is considered to have a significant influence on the hotel's financial success and customer connections. The staff has a major impact on the development of expectations, controlling and managing the customer experience and shaping the overall estimation of the service received by customers.

The overall performance values (i.e., the distance to 0) shown in Table 9 indicate that there is room for improvement. The value is $33.67 \%$ for NSD performance, $31.58 \%$ for CM performance, and $39.89 \%$ for finance performance. Therefore, in terms of service performance, financial performance has the lowest performance value and should be the first priority for enhancement if decision makers wish to achieve optimal performance.

For long-term enhancement, administrators should manage internal motivation carefully, as noted previously. This study's examination of strategic orientations for service models can be extended to most of the hotel industry. Nevertheless, decision makers should be cautious when using this model. The significance of the 10 criteria could vary. Hoteliers should compare strategic orientations and identify specific service performance levels before making decisions about the optimal strategic orientation.

\section{Conclusions}

The main objective of the present research was to estimate the interrelationship among strategic orientations from the perspective of the most important strategic orientations in the context of the hotel industry. To attain this purpose, a research framework was developed. A literature review on strategic orientations and service performance was conducted and the validation of these influential factors from the multi-perspective framework with experts by means of an MCDM tool carried out. A combination of the rough number and the DANP approach was proposed for the evaluation of strategic orientations according to different strategic perspectives. The interrelationship and the importance of each factor was provided separated for each perspective, and in aggregated form (overall perspective). Additionally, a straightforward optimal solution process was developed by applying the utility degree of alternatives through attribute values expressed as intervals which was also introduced to help evaluate relationships among multiple experts. Therefore, NSD, CM and financial values among service performances can achieve their aspired values.

Regarding the managerial implications, management has a role in estimating service performance in the hotel industry, by categorizing and prioritizing service performance evaluation within the strategic orientation framework to ensure its effective application for sustainable service development. This investigation suggests a comprehensive and easily applicable MCDM model that can be used to help disentangle selection decisions and strategic orientation formulation in the hotel industry. The investigation is focused on survey-based analysis and multi-criteria for strategic orientation schemes in Taiwan's hotel industry. To the best of our knowledge, this is the only example of an approach addressing the strategic orientation from the perspective of hotels in Taiwan. It is shown that strategic orientation initiatives in Taiwan are generally perceived within an interaction orientation, rather than within the totality of systemic efforts towards multi-faceted issues encompassing market orientation, and entrepreneurial orientation perspectives. Hence, this investigation is significant 
in that it putts forward and presents observations of the strategic orientations common in Taiwan's hotel industry. A flexible, practical and useful model for determining the hierarchical determinants of a strategic orientations programs for the hotel industry is proposed. The criteria are ordered by the DEMATEL, DANP and modified COPRAS-G methodologies. Although the model offered is universal, the perceptions of strategic orientations by experts in Taiwan could be considered a constraint. However, strategic orientations as well as the nature of the marketplace and service development are diverse in different regions around the world. Consequently, if the hotel industry wishes to advantage of scientific models like this approach offers, regional applications have to be developed to improve competitiveness in the wider marketplace. This model can be adapted for use in various parts of the world but outcomes will differ. The outcomes can help planners design specific strategic orientation activities suited to specific geographies. A further extension of this approach would be to benchmark specific groups or pairs of strategic orientations implementation objectives to find the ones which are more favorable. Such an investigation could improve the awareness of the areas most in need of enhancement in strategic orientation planning by comparing different implementations.

Although this study was thorough, there are opportunities for future research. Concerning the adopted solution methodology, even with all the advantages of rough number based DEMATEL, DANP and modified COPRAS-G, there some limitations. First, this study was conducted by collecting the opinions of a relatively small number of domain experts. A larger sample would have allowed a more sophisticated analysis of the estimation processes and more generalizable results. Second, the strategic orientation estimation criteria were selected from a review of prior studies on market orientation, entrepreneurial orientation, and interaction orientation estimation and thus may have excluded some influences on the service evaluation procedure. Future studies could use different methods such as interviews and longitudinal studies to identify other elements. Finally, to offer more objective information on the applicability of the proposed strategic orientation estimation model, future studies could employ case studies of specific performance estimates and thus prove the practicality of the general estimation structure for the hotel industry estimation and strategic orientation proposed herein.

\section{References}

Aboelmaged, M. (2018). Direct and indirect effects of eco-innovation, environmental orientation and supplier collaboration on hotel performance: An empirical study. Journal of Cleaner Production, 184(20), 537-549. https://doi.org/10.1016/j.jclepro.2018.02.192

Brower, J., \& Rowe, K. (2017). Where the eyes go, the body follows?: Understanding the impact of strategic orientation on corporate social performance. Journal of Business Research, 79, 134-142. https://doi.org/10.1016/j.jbusres.2017.06.004

Chen, C. Y., Tzeng, G. H., \& Huang, J. J. (2018). Generalized DEMATEL technique with centrality measurements. Technological and Economic Development of Economy, 24(2), 600-614. https://doi.org/10.3846/20294913.2016.1216471

Chen, Y. C., Li, P. C., \& Kenneth, R. E. (2012). Effects of interaction and entrepreneurial orientation on organizational performance: Insights into market driven and market driving. Industrial Marketing Management, 41(6), 1019-1034. https://doi.org/10.1016/j.indmarman.2012.01.017 
Day, G. S. (1994). The capabilities of market-driven organizations. Journal of Marketing, 58, 37-52. https://doi.org/10.1177/002224299405800404

Deng, J. L. (1982). Control problems of grey system. Systems and Control Letters, 1(5), 288-294. https://doi.org/10.1016/S0167-6911(82)80025-X

Fernández-Mesa, A., \& Alegre, J. (2015). Entrepreneurial orientation and export intensity: Examining the interplay of organizational learning and innovation. International Business Review, 24(1), 148156. https://doi.org/10.1016/j.ibusrev.2014.07.004

García-Villaverde, P. M., Elche, D., \& Martínez-Pérez, Á. (2017). Determinants of radical innovation in clustered firms of the hospitality and tourism industry. International Journal of Hospitality Management, 61, 45-58. https://doi.org/10.1016/j.ijhm.2016.11.002

Hartman, S., \& Lundberg, O. (1995). Information processing techniques in planning: An investigation of preferences of executive planners. Journal of Business Research, 33(1), 13-24.

https://doi.org/10.1016/0148-2963(94)00002-V

Hashemkhani Zolfani, S., Chen, I. S., Rezaeiniya, N., \& Tamošaitienė, J. (2012). A hybrid MCDM model encompassing AHP and COPRAS-G methods for selecting company supplier in Iran. Technological and Economic Development of Economy, 18(3), 529-543. https://doi.org/10.3846/20294913.2012.709472

Hu, K. H., Jianguo, W., \& Tzeng, G. H. (2018). Improving China’s regional financial center modernization development using a new hybrid MADM model. Technological and Economic Development of Economy, 24(2), 429-466. https://doi.org/10.3846/20294913.2016.1213195

Hult, G. T. M., \& Ketchen, D. J. (2001). Does market orientation matter? A test of the relationship between positional advantage and performance. Strategic Management Journal, 22(9), 899-906. https://doi.org/10.1002/smj.197

Jiang, X., Liu, H., Fey, C., \& Jiang, F. (2018). Entrepreneurial orientation, network resource acquisition, and firm performance: A network approach. Journal of Business Research, 87, 46-57. https://doi.org/10.1016/j.jbusres.2018.02.021

Jiang, Y., \& Kim, Y. (2015). Developing multi-dimensional green value: extending social exchange theory to explore customers' purchase intention in green hotels - evidence from Korea. International Journal of Contemporary Hospitality Management, 27(2), 308-334. https://doi.org/10.1108/IJCHM-08-2013-0383

Jorgensen, B. (2004). Individual and organizational learning: A model for reform for public organizations. Foresight - The Journal of Future Studies, Strategic Thinking and Policy, 6(2), 91-103.

Ketchen, D. J., Thomas, J. B., \& McDaniel, R. R. (1996). Process, content and context: synergistic effects on organizational performance. Journal of Management, 22(2), 231-257. https://doi.org/10.1177/014920639602200203

Kraus, S. (2013). The role of entrepreneurial orientation in service firms: empirical evidence from Austria. The Service Industries Journal, 33(5), 427-444. https://doi.org/10.1080/02642069.2011.622373

Koch, J. V., \& Cebula, R. J. (2002). Price, quality and service on the Internet: sense and nonsense. Contemporary Economic Policy, 20(1), 25-37. https://doi.org/10.1093/cep/20.1.25

Kumar, V., \& Ramani, G. (2006). Interaction orientation: The new marketing competency in Does Marketing Need Reform. In. J. N. Sheth, \& R. S. Sisodia (Eds.), Armonk (pp. 109-118). NY: M.E Sharpe, Inc.

Liou, J. J. H., Tamosaitiene, J., Zavadskas, E. K., \& Tzeng, G. H. (2016). New hybrid COPRAS-G MADM Model for improving and selecting suppliers in green supply chain management. International Journal of Production Research, 54(1), 114-134. https://doi.org/10.1080/00207543.2015.1010747

Lu, M. T., Lin, S. W., \& Tzeng, G. H. (2013). Improving RFID adoption in Taiwan's healthcare industry based on a DEMATEL technique with a hybrid MCDM model. Decision Support System, 56, 259269. https://doi.org/10.1016/j.dss.2013.06.006 
Lu, M. T., Tzeng, G. H., \& Tang, L. L. (2013). Environmental strategic orientations for improving green innovation performance in fuzzy environment- Using new fuzzy hybrid MCDM model. International Journal of Fuzzy Systems, 15(3), 297-316.

Lu, M. T., Hsu, C. C., Liou, J. J. H., \& Lo, H. W. (2018). A hybrid MCDM and sustainability-balanced scorecard model to establish sustainable performance evaluation for international airports. Journal of Air Transport Management, 71, 9-19. https://doi.org/10.1016/j.jairtraman.2018.05.008

Lu, M. T., Hu, S. K., Huang, L. H., \& Tzeng, G. H. (2015). Evaluating the implementation of businessto-business $\mathrm{m}$-commerce by SMEs based on a new hybrid MADM model. Management Decision, 53(2), 290-317. https://doi.org/10.1108/MD-01-2014-0012

Lukas, B. A., \& Maignan, I. (1996). Striving for quality: the key role of internal and external customers. Journal of Market-Focused Management, 1(2), 175-187. https://doi.org/10.1007/BF00128689

Matsuno, K., Mentzer, J. T., \& Ozsomer, A. (2002). The effects of entrepreneurial proclivity and market orientation on business performance. Journal of Marketing, 66(3), 18-32. https://doi.org/10.1509/jmkg.66.3.18.18507

Miller, G. A. (2003). Consumerism in sustainable tourism: a survey of UK consumers. Journal of Sustainable Tourism, 11(1), 17-39. https://doi.org/10.1080/09669580308667191

Mintzberg, H. A., \& Lampel, B. J. (1998). Strategy safari: a guided tour through the wilds of strategic management. New York: Free Press.

Noble, C. H., Sinha, R. K., \& Kumar, A. (2002). Market orientation and alternative strategic orientations: a longitudinal assessment of performance implications. Journal of Marketing, 66(4), 25-39. https://doi.org/10.1509/jmkg.66.4.25.18513

Narver, J. C., \& Slater, S. F. (1990). The effect of a market orientation on business profitability. Journal of Marketing, 54(4), 20-35. https://doi.org/10.1177/002224299005400403

Naman, J. L., \& Slevin, D. P. (1993). Entrepreneurship and the concept of fit: A model and empirical tests. Strategic Management Journal, 14(2), 137-153. https://doi.org/10.1002/smj.4250140205

OCDE. (2003). Facteurs exogenes recents (guerre, terrorisme, SRAS) ayant un impact significatif sur le tourisme, mesures prises pour y faire face et consequences structurelles. Session speciale du Comite du tourisme de l'OCDE, 10 July. OECD, Paris.

Pawlak, Z. (1982). Rough sets. International Journal of Computer and Information Science, 11(5), 341356. https://doi.org/10.1007/BF01001956

Peng, M. W. (2003). Institutional transitions and strategic choices. Academy of Management Review, 28, 275-296. https://doi.org/10.5465/amr.2003.9416341

Qu, R., \& Zhang, Z. (2015). Market orientation and business performance in MNC foreign subsidiariesModerating effects of integration and responsiveness. Journal of Business Research, 68(5), 919-924. https://doi.org/10.1016/j.jbusres.2014.09.018

Ramani, G., \& Kumar, V. (2008). Interaction orientation and firm performance. Journal of Marketing, 72(1), 27-45. https://doi.org/10.1509/jmkg.72.1.027

Rauch, A., Wiklund, J., Lumpkin, G., \& Frese, M. (2009). Entrepreneurial orientation and business performance: An assessment of past research and suggestions for the future. Entrepreneurship: Theory \& Practice, 33(3), 761-787. https://doi.org/10.1111/j.1540-6520.2009.00308.x

Rowley, J. (2004). Online branding. Online Information Review, 28(2), 131-138. https://doi.org/10.1108/14684520410531637

Shen, K. Y., Hu, S. K., \& Tzeng, G. H. (2017). Financial modelling and improvement planning for the life insurance industry by using a rough knowledge based hybrid MCDM model. Information Sciences, 375, 296-313. https://doi.org/10.1016/j.ins.2016.09.055

Slater, S. F., \& Narver, J. C. (1995). Market orientation and the learning organization. Journal of Marketing, 59(3), 63-74. https://doi.org/10.1177/002224299505900306 
Skogland, I., \& Siguaw, J. A. (2004). Are your satisfied customers loyal? Cornell Hotel and Restaurant Administration Quarterly, 45(3), 221-234. https://doi.org/10.1177/0010880404265231

Slater, S. F., \& Narver, J. C. (1994). Market orientation, customer value, and superior performance. Business Horizons, 37(2), 22-28. https://doi.org/10.1016/0007-6813(94)90029-9

Song, W., Ming, X., \& Liu, H. C. (2017a). Identifying critical risk factors of sustainable supply chain management: A rough strength-relation analysis method. Journal of Cleaner Production, 143, 100115. https://doi.org/10.1016/j.jclepro.2016.12.145

Song, W., Ming, X., \& Wu, Z. (2013). An integrated rough number-based approach to design concept evaluation under subjective environments. Journal of Engineering Design, 24(5), 320-341. https://doi.org/10.1080/09544828.2012.732994

Song, W., Xu, Z., \& Liu, H. C. (2017b). Developing sustainable supplier selection criteria for solar airconditioner manufacturer: An integrated approach. Renewable and Sustainable Energy Reviews, 79, 1461-1471. https://doi.org/10.1016/j.rser.2017.05.081

Srivastava, R. K., Shervani, T. A., \& Fahey, L. (1999). Marketing, business processes and shareholder value: an organizationally embedded view of marketing activities. Journal of Marketing, 63, 168-179. https://doi.org/10.1177/00222429990634s116

Su, C. M., Horng, D. J., Tseng, M. L., Chiu, A. S. F., Wu, K. J., \& Chen, H. P. (2016). Improving sustainable supply chain management using a novel hierarchical grey-DEMATEL approach. Journal of Cleaner Production, 134, 469-481. https://doi.org/10.1016/j.jclepro.2015.05.080

Tajeddini, K., \& Trueman, M. (2014). Perceptions of innovativeness among Iranian hotel managers. Journal of Hospitality and Tourism Technology, 5(1), 62-77. https://doi.org/10.1108/JHTT-12-2012-0036

Tajeddini, K. (2010). Effect of customer orientation and entrepreneurial orientation on innovativeness: evidence from the hotel industry in Switzerland. Tourism Management, 31(2), 221-231. https://doi.org/10.1016/j.tourman.2009.02.013

Tajeddini, K., \& Trueman, M. (2012). Managing Swiss hospitality: how cultural antecedents of innovation and customer-oriented value systems can influence performance in the hotel industry. International Journal of Hospitality Management, 31, 1119-1129. https://doi.org/10.1016/j.ijhm.2012.01.009

Tajeddini, K. (2011). Customer orientation, learning orientation, and new service development: An empirical investigation of the Swiss hotel industry. Journal of Hospitality and Tourism Research, 35(4), 437-468. https://doi.org/10.1177/1096348010380599

Tajeddini, K., Altinay, L., \& Ratten, V. (2017). Service innovativeness and the structuring of organizations: The moderating roles of learning orientation and inter-functional coordination. International Journal of Hospitality Management, 65, 100-114. https://doi.org/10.1016/j.ijhm.2017.06.010

Tung, W., Liang, A. R. D., \& Chen, S. C. (2014). The influence of service orientation and interaction orientation on consumer identification. The Service Industries Journal, 34(5), 439-454. https://doi.org/10.1080/02642069.2014.871533

Varadarajan, P. R., \& Clark, T. (1994). Delineating the scope of corporate, business, and marketing strategy. Journal of Business Research, 31(2), 93-105. https://doi.org/10.1016/0148-2963(94)90074-4

Veliyath, R., \& Shortell, S. M. (1993). Strategic orientation, strategic planning system characteristics and performance. Journal of Management Studies, 30(3), 359-381.

https://doi.org/10.1111/j.1467-6486.1993.tb00309.x

Wang, C. L. (2008). Entrepreneurial orientation, learning orientation, and firm performance. Entrepreneurship Theory and Practice, 32(4), 635-657. https://doi.org/10.1111/j.1540-6520.2008.00246.x

Walker, Jr. O. C., \& Ruekert, R. W. (1987). Marketing's role in the implementation of business strategies: a critical review and conceptual framework. The Journal of Marketing, 51(3), 15-33.

https://doi.org/10.1177/002224298705100302 
Yeo, R. (2007). Organizational learning in representative Singapore public organizations: a study of its contribution to the understanding of management in Singapore. International Journal of Public Sector Management, 20(5), 345-365. https://doi.org/10.1108/09513550710772486

Zahay, D. L., \& Handfield, R. B. (2004). The role of learning and technical capabilities in predicting adoption of B2B technologies. Industrial Marketing Management, 33, 627-641.

https://doi.org/10.1016/j.indmarman.2003.10.004

Zavadskas, E. K., Kaklauskas, A., Turskis, Z., \& Tamošaitienè, J. (2008). Selection of the effective dwelling house walls by applying attributes values determined at intervals. Journal of Civil Engineering and Management, 14(2), 85-93. https://doi.org/10.3846/1392-3730.2008.14.3

Zhai, L. Y., Khoo, L. P., \& Zhong, Z. W. (2008). A rough set enhanced fuzzy approach to quality function deployment. The International Journal of Advanced Manufacturing Technology, 37(5), 613-624. https://doi.org/10.1007/s00170-007-0989-9

Zhou, K. Z., Yim, B. C., \& Tse, D. K. (2005). The effects of strategic orientations on technology- and market-based breakthrough innovations. Journal of Marketing, 69(2), 42-60.

https://doi.org/10.1509/jmkg.69.2.42.60756

Zhu, G. N., Hu, J., Qi, J., Gu, C. C., \& Peng, Y. H. (2015). An integrated AHP and VIKOR for design concept evaluation based on rough number. Advanced Engineering Informatics, 29(3), 408-418. https://doi.org/10.1016/j.aei.2015.01.010

\section{APPENDIX A.1}

\section{Raw influential relationship data for rough DANP approach}

Table A.1. Raw influential data from 10 domain experts

\begin{tabular}{|c|c|c|c|c|c|c|c|c|c|c|c|}
\hline \multirow{2}{*}{ Criterion } & \multicolumn{10}{|c|}{ Respondent (domain expert) } & \multirow{2}{*}{$\begin{array}{l}\text { Rough } \\
\text { number }\end{array}$} \\
\hline & No.1 & No. 2 & No.3 & No.4 & No.5 & No.6 & No.7 & No. 8 & No.9 & No.10 & \\
\hline$C_{11}-C_{11}$ & 0 & 0 & 0 & 0 & 0 & 0 & 0 & 0 & 0 & 0 & {$[0.00,0.00]$} \\
\hline$C_{12-C^{11}}$ & 3 & 2 & 1 & 3 & 3 & 3 & 4 & 4 & 3 & 3 & {$[2.41,3.35]$} \\
\hline$C_{13}-C_{11}$ & 2 & 1 & 2 & 2 & 4 & 4 & 3 & 3 & 2 & 3 & {$[2.02,3.19]$} \\
\hline$C_{21}-C_{11}$ & 3 & 4 & 2 & 4 & 4 & 3 & 4 & 4 & 1 & 3 & {$[2.57,3.75]$} \\
\hline$C_{22}-C_{11}$ & 3 & 1 & 3 & 3 & 3 & 3 & 2 & 3 & 1 & 3 & {$[2.08,2.89]$} \\
\hline$C_{23}-C_{11}$ & 3 & 4 & 4 & 3 & 4 & 3 & 3 & 3 & 2 & 3 & {$[2.87,3.52]$} \\
\hline$C_{31}-C_{11}$ & 4 & 4 & 4 & 3 & 3 & 4 & 4 & 4 & 4 & 4 & {$[3.64,3.96]$} \\
\hline$C_{32}-C_{11}$ & 4 & 4 & 4 & 3 & 4 & 4 & 2 & 4 & 3 & 3 & {$[3.13,3.85]$} \\
\hline$C_{33}-C_{11}$ & 4 & 3 & 4 & 3 & 4 & 4 & 2 & 4 & 4 & 4 & {$[3.25,3.92]$} \\
\hline$C_{34}-C_{11}$ & 4 & 4 & 4 & 3 & 4 & 4 & 2 & 4 & 4 & 3 & {$[3.25,3.92]$} \\
\hline$C_{11} C_{12}$ & 3 & 1 & 2 & 3 & 3 & 4 & 2 & 4 & 4 & 3 & {$[2.28,3.48]$} \\
\hline$C_{12}-C_{12}$ & 0 & 0 & 0 & 0 & 0 & 0 & 0 & 0 & 0 & 0 & {$[0.00,0.00]$} \\
\hline$C_{13}-C_{12}$ & 3 & 2 & 2 & 2 & 2 & 4 & 3 & 3 & 3 & 2 & {$[2.24,2.98]$} \\
\hline$C_{21}-C_{12}$ & 3 & 4 & 2 & 3 & 3 & 2 & 3 & 4 & 3 & 4 & {$[2.69,3.51]$} \\
\hline$C_{22}-C_{12}$ & 2 & 4 & 3 & 3 & 2 & 3 & 2 & 3 & 1 & 4 & {$[2.12,3.27]$} \\
\hline$C_{23}-C_{12}$ & 3 & 4 & 3 & 3 & 4 & 3 & 3 & 4 & 3 & 4 & {$[3.16,3.64]$} \\
\hline$C_{31}-C_{12}$ & 3 & 2 & 2 & 3 & 2 & 4 & 2 & 4 & 3 & 3 & {$[2.36,3.25]$} \\
\hline$C_{32}-C_{12}$ & 3 & 2 & 2 & 2 & 0 & 3 & 3 & 4 & 3 & 3 & {$[1.87,3.07]$} \\
\hline
\end{tabular}


Continue of Table A.1

\begin{tabular}{|c|c|c|c|c|c|c|c|c|c|c|c|}
\hline \multirow{2}{*}{ Criterion } & \multicolumn{10}{|c|}{ Respondent (domain expert) } & \multirow{2}{*}{$\begin{array}{l}\text { Rough } \\
\text { number }\end{array}$} \\
\hline & No.1 & No. 2 & No.3 & No.4 & No.5 & No.6 & No.7 & No.8 & No.9 & No.10 & \\
\hline$C_{33}-C_{12}$ & 3 & 1 & 2 & 3 & 1 & 3 & 3 & 3 & 4 & 3 & {$[2.06,3.11$} \\
\hline$C_{34}-C_{12}$ & 3 & 2 & 2 & 3 & 1 & 2 & 3 & 3 & 3 & 3 & {$[2.13,2.85$} \\
\hline$C_{11}-C_{13}$ & 4 & 2 & 4 & 2 & 4 & 4 & 3 & 3 & 2 & 3 & {$[2.59,3.60$} \\
\hline$C_{12}-C_{13}$ & 3 & 1 & 4 & 2 & 2 & 4 & 3 & 4 & 3 & 2 & {$[2.15,3.43$} \\
\hline$C_{13}-C_{13}$ & 0 & 0 & 0 & 0 & 0 & 0 & 0 & 0 & 0 & 0 & {$[0.00,0.00$} \\
\hline$C_{21}-C_{13}$ & 2 & 0 & 1 & 2 & 4 & 4 & 2 & 3 & 2 & 1 & {$[1.29,2.93$} \\
\hline$C_{22}-C_{13}$ & 1 & 1 & 3 & 2 & 3 & 3 & 3 & 2 & 3 & 2 & {$[1.83,2.75$} \\
\hline$C_{23}-C_{13}$ & 3 & 3 & 3 & 2 & 4 & 2 & 3 & 3 & 2 & 1 & {$[2.11,3.08$} \\
\hline$C_{31}-C_{13}$ & 3 & 2 & 4 & 2 & 2 & 3 & 3 & 3 & 3 & 2 & {$[2.35,3.06$} \\
\hline$C_{32}-C_{13}$ & 2 & 2 & 4 & 2 & 1 & 3 & 3 & 3 & 2 & 2 & {$[1.92,2.89$} \\
\hline$C_{33}-C_{13}$ & 2 & 1 & 1 & 2 & 3 & 3 & 2 & 3 & 3 & 3 & {$[1.83,2.75$} \\
\hline$C_{34}-C_{13}$ & 3 & 1 & 0 & 2 & 2 & 2 & 2 & 3 & 2 & 2 & {$[1.41,2.35$} \\
\hline$C_{11}-C_{21}$ & 3 & 4 & 4 & 4 & 4 & 3 & 4 & 4 & 2 & 3 & {$[3.13,3.85$} \\
\hline$C_{12}-C_{21}$ & 3 & 3 & 3 & 3 & 4 & 4 & 3 & 4 & 4 & 4 & {$[3.25,3.75$} \\
\hline$C_{13}-C_{21}$ & 3 & 0 & 3 & 2 & 4 & 2 & 2 & 3 & 2 & 1 & {$[1.47,2.89$} \\
\hline$C_{21}-C_{21}$ & 0 & 0 & 0 & 0 & 0 & 0 & 0 & 0 & 0 & 0 & {$[0.00,0.00$} \\
\hline$C_{22}-C_{21}$ & 4 & 1 & 3 & 3 & 3 & 2 & 3 & 4 & 2 & 4 & {$[2.28,3.48$} \\
\hline$C_{23}-C_{21}$ & 4 & 4 & 4 & 2 & 4 & 4 & 3 & 3 & 4 & 4 & {$[3.25,3.92$} \\
\hline$C_{31}-C_{21}$ & 4 & 4 & 3 & 3 & 3 & 3 & 2 & 4 & 3 & 4 & {$[2.94,3.65$} \\
\hline$C_{32}-C_{21}$ & 3 & 2 & 4 & 3 & 2 & 2 & 3 & 3 & 1 & 4 & {$[2.12,2.89$} \\
\hline$C_{33}-C_{21}$ & 3 & 4 & 2 & 3 & 3 & 3 & 2 & 2 & 2 & 4 & {$[2.36,2.75$} \\
\hline$C_{34}-C_{21}$ & 2 & 4 & 1 & 3 & 3 & 4 & 3 & 3 & 3 & 3 & {$[2.41,2.35$} \\
\hline$C_{11}-C_{22}$ & 3 & 2 & 4 & 3 & 3 & 4 & 4 & 4 & 1 & 3 & {$[2.49,3.64$} \\
\hline$C_{12}-C_{22}$ & 3 & 4 & 2 & 3 & 2 & 3 & 4 & 4 & 2 & 4 & {$[2.59,3.60$} \\
\hline$C_{13}-C_{22}$ & 1 & 2 & 1 & 2 & 3 & 2 & 3 & 4 & 1 & 2 & {$[1.52,2.73$} \\
\hline$C_{21}-C_{22}$ & 4 & 3 & 3 & 3 & 3 & 4 & 3 & 4 & 2 & 4 & {$[2.94,3.65$} \\
\hline$C_{22}-C_{22}$ & 0 & 0 & 0 & 0 & 0 & 0 & 0 & 0 & 0 & 0 & {$[0.00,0.00$} \\
\hline$C_{23}-C_{22}$ & 4 & 3 & 2 & 2 & 4 & 4 & 3 & 4 & 3 & 4 & {$[2.83,3.75$} \\
\hline$C_{31}-C_{22}$ & 3 & 3 & 1 & 3 & 3 & 3 & 2 & 3 & 2 & 3 & {$[2.25,2.92$} \\
\hline$C_{32}-C_{22}$ & 1 & 2 & 2 & 3 & 3 & 3 & 2 & 3 & 1 & 4 & {$[1.81,2.99$} \\
\hline$C_{33}-C_{22}$ & 1 & 2 & 2 & 3 & 0 & 2 & 2 & 2 & 3 & 4 & {$[1.42,2.76$} \\
\hline$C_{34}-C_{22}$ & 3 & 4 & 2 & 3 & 1 & 3 & 3 & 3 & 2 & 3 & {$[2.24,3.13$} \\
\hline$C_{11}-C_{23}$ & 2 & 2 & 4 & 3 & 4 & 2 & 4 & 4 & 1 & 3 & {$[2.22,3.56$} \\
\hline$C_{12}-C_{23}$ & 3 & 2 & 3 & 3 & 4 & 4 & 3 & 4 & 4 & 4 & {$[3.02,3.76$} \\
\hline$C_{13}-C_{23}$ & 2 & 4 & 1 & 2 & 4 & 1 & 3 & 3 & 2 & 1 & {$[1.59,3.05$} \\
\hline$C_{21}-C_{23}$ & 3 & 2 & 3 & 2 & 4 & 4 & 3 & 3 & 4 & 4 & {$[2.75,3.64$} \\
\hline$C_{22}-C_{23}$ & 3 & 3 & 1 & 2 & 4 & 3 & 3 & 4 & 3 & 4 & {$[2.44,3.51$} \\
\hline$C_{23}-C_{23}$ & 0 & 0 & 0 & 0 & 0 & 0 & 0 & 0 & 0 & 0 & {$[0.00,0.00$} \\
\hline$C_{31}-C_{23}$ & 3 & 1 & 1 & 3 & 4 & 3 & 4 & 3 & 3 & 3 & {$[2.26,3.31$} \\
\hline$C_{32}-C_{23}$ & 3 & 2 & 4 & 3 & 4 & 3 & 3 & 4 & 2 & 4 & {$[2.75,3.64$} \\
\hline$C_{33}-C_{23}$ & 3 & 2 & 4 & 3 & 2 & 3 & 4 & 3 & 2 & 3 & {$[2.49,3.31$} \\
\hline
\end{tabular}


End of Table A.1

\begin{tabular}{|c|c|c|c|c|c|c|c|c|c|c|c|}
\hline \multirow{2}{*}{ Criterion } & \multicolumn{10}{|c|}{ Respondent (domain expert) } & \multirow{2}{*}{$\begin{array}{l}\text { Rough } \\
\text { number }\end{array}$} \\
\hline & No.1 & No. 2 & No.3 & No.4 & No.5 & No.6 & No.7 & No.8 & No.9 & No.10 & \\
\hline$C_{34}-C_{23}$ & 2 & 3 & 4 & 3 & 3 & 3 & 3 & 4 & 2 & 3 & {$[2.65,3.35]$} \\
\hline$C_{11}-C_{31}$ & 4 & 4 & 4 & 3 & 3 & 4 & 4 & 4 & 4 & 4 & {$[3.64,3.96]$} \\
\hline$C_{12}-C_{31}$ & 3 & 3 & 0 & 3 & 2 & 3 & 3 & 4 & 3 & 3 & {$[2.16,3.16$} \\
\hline$C_{13}-C_{31}$ & 2 & 1 & 1 & 2 & 2 & 2 & 2 & 3 & 3 & 2 & {$[1.65,2.35]$} \\
\hline$C_{21}-C_{31}$ & 3 & 4 & 3 & 3 & 3 & 4 & 3 & 4 & 3 & 4 & {$[3.16,3.64]$} \\
\hline$C_{22}-C_{31}$ & 3 & 1 & 0 & 3 & 3 & 4 & 3 & 4 & 3 & 3 & {$[2.02,3.32]$} \\
\hline$C_{23}-C_{31}$ & 3 & 4 & 0 & 3 & 4 & 3 & 3 & 3 & 2 & 3 & {$[2.16,3.34]$} \\
\hline$C_{31}-C_{31}$ & 0 & 0 & 0 & 0 & 0 & 0 & 0 & 0 & 0 & 0 & {$[0.00,0.00]$} \\
\hline$C_{32}-C_{31}$ & 3 & 4 & 0 & 3 & 4 & 3 & 3 & 3 & 2 & 3 & {$[3.13,3.85]$} \\
\hline$C_{33}-C_{31}$ & 4 & 3 & 4 & 3 & 4 & 4 & 3 & 4 & 3 & 4 & {$[3.36,3.84]$} \\
\hline$C_{34}-C_{31}$ & 3 & 4 & 4 & 3 & 3 & 1 & 3 & 4 & 2 & 2 & {$[2.28,3.48]$} \\
\hline$C_{11}-C_{32}$ & 4 & 4 & 4 & 3 & 4 & 4 & 4 & 4 & 3 & 3 & {$[3.49,3.91]$} \\
\hline$C_{12}-C_{32}$ & 2 & 3 & 0 & 2 & 0 & 3 & 3 & 4 & 2 & 3 & {$[1.38,2.95]$} \\
\hline$C_{13}-C_{32}$ & 2 & 1 & 3 & 2 & 1 & 2 & 3 & 3 & 4 & 2 & {$[1.73,2.89]$} \\
\hline$C_{21}-C_{32}$ & 1 & 4 & 2 & 3 & 2 & 4 & 3 & 3 & 4 & 4 & {$[2.33,3.62]$} \\
\hline$C_{22}-C_{32}$ & 1 & 1 & 0 & 3 & 3 & 4 & 3 & 4 & 3 & 4 & {$[1.71,3.41]$} \\
\hline$C_{23}-C_{32}$ & 2 & 1 & 0 & 3 & 4 & 3 & 3 & 4 & 4 & 4 & {$[1.87,3.60]$} \\
\hline$C_{31}-C_{32}$ & 3 & 4 & 4 & 3 & 4 & 3 & 2 & 3 & 3 & 3 & {$[2.87,3.52]$} \\
\hline$C_{32}-C_{32}$ & 0 & 0 & 0 & 0 & 0 & 0 & 0 & 0 & 0 & 0 & {$[0.00,0.00]$} \\
\hline$C_{33}-C_{32}$ & 4 & 3 & 4 & 3 & 3 & 4 & 3 & 4 & 2 & 3 & {$[2.94,3.65]$} \\
\hline$C_{34}-C_{32}$ & 3 & 4 & 4 & 3 & 3 & 2 & 3 & 3 & 3 & 2 & {$[2.65,3.35$} \\
\hline$C_{11}-C_{33}$ & 3 & 4 & 4 & 3 & 4 & 3 & 4 & 4 & 3 & 4 & {$[3.36,3.84]$} \\
\hline$C_{12}-C_{33}$ & 3 & 3 & 0 & 3 & 1 & 2 & 3 & 3 & 2 & 3 & {$[1.68,2.84]$} \\
\hline$C_{13}-C_{33}$ & 2 & 1 & 0 & 2 & 3 & 1 & 2 & 3 & 2 & 3 & {$[1.28,2.48]$} \\
\hline$C_{21}-C_{33}$ & 1 & 3 & 1 & 3 & 3 & 4 & 3 & 3 & 4 & 4 & {$[2.28,3.47]$} \\
\hline$C_{22}-C_{33}$ & 2 & 1 & 1 & 3 & 0 & 4 & 2 & 3 & 3 & 4 & {$[1.40,3.16]$} \\
\hline$C_{23}-C_{33}$ & 1 & 1 & 0 & 3 & 2 & 3 & 3 & 3 & 3 & 3 & {$[1.55,2.80]$} \\
\hline$C_{31}-C_{33}$ & 4 & 1 & 4 & 3 & 4 & 3 & 2 & 3 & 3 & 4 & {$[2.49,3.64]$} \\
\hline$C_{32}-C_{33}$ & 4 & 1 & 4 & 3 & 3 & 3 & 4 & 4 & 3 & 3 & {$[2.71,3.64]$} \\
\hline$C_{33}-C_{33}$ & 0 & 0 & 0 & 0 & 0 & 0 & 0 & 0 & 0 & 0 & {$[0.00,0.00]$} \\
\hline$C_{34}-C_{33}$ & 3 & 1 & 4 & 4 & 2 & 2 & 3 & 4 & 4 & 1 & {$[2.02,3.54]$} \\
\hline$C_{11}-C_{34}$ & 3 & 4 & 4 & 3 & 4 & 3 & 3 & 4 & 4 & 3 & {$[3.25,3.75]$} \\
\hline$C_{12}-C_{34}$ & 2 & 3 & 0 & 3 & 1 & 2 & 3 & 4 & 3 & 3 & {$[1.65,3.07]$} \\
\hline$C_{13}-C_{34}$ & 1 & 1 & 0 & 2 & 2 & 1 & 3 & 4 & 2 & 2 & {$[1.11,2.53]$} \\
\hline$C_{21}-C_{34}$ & 0 & 3 & 3 & 3 & 3 & 4 & 3 & 4 & 3 & 3 & {$[2.42,3.35]$} \\
\hline$C_{22}-C_{34}$ & 1 & 1 & 0 & 3 & 1 & 4 & 2 & 3 & 2 & 3 & {$[1.19,2.81]$} \\
\hline$C_{23}-C_{34}$ & 1 & 4 & 1 & 3 & 3 & 2 & 3 & 3 & 2 & 3 & {$[1.92,3.06]$} \\
\hline$C_{31}-C_{34}$ & 4 & 4 & 4 & 3 & 3 & 3 & 3 & 4 & 4 & 2 & {$[3.02,3.76]$} \\
\hline$C_{32}-C_{34}$ & 3 & 4 & 4 & 3 & 3 & 4 & 2 & 4 & 2 & 2 & {$[2.59,3.60]$} \\
\hline$C_{33^{-}} C_{34}$ & 3 & 2 & 4 & 4 & 2 & 4 & 3 & 4 & 4 & 1 & {$[2.42,3.72]$} \\
\hline$C_{34}-C_{34}$ & 0 & 0 & 0 & 0 & 0 & 0 & 0 & 0 & 0 & 0 & {$[0.00,0.00]$} \\
\hline
\end{tabular}




\section{APPENDIX A.2}

\section{Raw performance data for modified COPRAS-G method}

Table A.2. Raw performance data from 10 domain experts

\begin{tabular}{|c|c|c|c|c|c|c|}
\hline \multirow[b]{2}{*}{ Criteria } & \multicolumn{2}{|c|}{ NSD performance } & \multicolumn{2}{|c|}{ CM performance } & \multicolumn{2}{|c|}{ Financial performance } \\
\hline & crisp & $\begin{array}{l}\text { Rough } \\
\text { number }\end{array}$ & crisp & $\begin{array}{l}\text { Rough } \\
\text { number }\end{array}$ & crisp & $\begin{array}{l}\text { Rough } \\
\text { number }\end{array}$ \\
\hline$C_{11}$ & $7,6,8,9,10,4,6,5,6,5$ & {$[5.36,7.97]$} & $9,10,10,9,10,8,7,9,8,8$ & {$[8.15,9.43]$} & $6,5,7,7,5,6,8,6,7,6$ & {$[5.73,6.89]$} \\
\hline$C_{12}$ & $6,8,7,7,5,7,6,4,5,7$ & {$[5.39,6.96]$} & $8,5,3,7,3,6,7,8,5,7$ & {$[4.63,7.04]$} & $5,9,5,6,2,7,7,4,7,7$ & {$[4.55,7.13]$} \\
\hline$C_{13}$ & $6,3,6,6,8,7,7,4,6,4$ & {$[4.69,6.67]$} & $7,6,4,5,4,8,7,7,6,3$ & {$[4.57,6.77]$} & $7,8,5,5,5,7,7,4,8,5$ & {$[5.23,6.96]$} \\
\hline$C_{21}$ & $8,9,10,8,10,9,7,9,8,8$ & {$[8.02,9.19]$} & $7,7,6,7,8,9,7,7,6,5$ & {$[6.24,7.58]$} & $4,5,7,6,5,7,7,6,5,6$ & {$[5.15,6.43]$} \\
\hline$C_{22}$ & $7,7,7,7,6,8,8,10,5,8$ & {$[6.48,8.14]$} & $6,5,7,7,6,8,7,7,5,6$ & {$[5.81,6.99]$} & $3,6,9,6,0,6,8,2,6,6$ & {$[3.45,6.83]$} \\
\hline$C_{23}$ & $6,8,8,5,7,9,8,5,5,8$ & {$[5.94,7.82]$} & $8,7,8,5,4,8,8,5,6,8$ & {$[5.72,7.61]$} & $5,8,9,5,1,8,8,3,7,6$ & {$[4.15,7.60]$} \\
\hline$C_{31}$ & $6,9,8,6,4,6,7,9,6,8$ & {$[5.88,7.90]$} & $8,7,9,5,8,8,8,7,8,9$ & {$[6.99,8.31]$} & $5,5,7,4,2,4,8,6,7,6$ & {$[4.14,6.58]$} \\
\hline$C_{32}$ & $6,7,9,6,7,8,7,5,6,6$ & {$[6.01,7.46]$} & $7,9,9,6,9,9,7,7,8,8$ & {$[7.22,8.56]$} & $6,7,8,4,2,8,7,5,6,6$ & {$[4.57,7.04]$} \\
\hline$C_{33}$ & $6,8,6,7,3,5,6,7,7,4$ & {$[4.84,6.85]$} & $9,6,9,7,6,7,6,9,7,8$ & {$[6.64,8.20]$} & $7,6,8,4,3,2,6,4,7,5$ & {$[3.82,6.53]$} \\
\hline$C_{34}$ & $5,5,3,7,1,3,8,7,8,4$ & {$[3.44,6.68]$} & $6,6,9,7,1,7,8,7,9,6$ & {$[5.16,7.84]$} & $6,10,8,4,1,8,8,6,6,5$ & {$[4.44,7.79]$} \\
\hline
\end{tabular}

\section{APPENDIX B}

\section{Methods used in the rough MAGDM model}

The methods employed in our proposed rough MAGDM model are the rough number, rough DANP, and modified COPRAS-G methods.

\section{APPENDIX B.1}

\section{The rough number method}

This method involves three steps:

\section{First step: Determine lower and upper approximations of the rough number}

Assume that $U$ is a set of the universe that contains all the objects and there is a set of $v$ classes of expert judgments. The $R=\left\{e_{1}, e_{2}, \ldots, e_{v}\right\}$ are ordered in the manner $e_{1}<e_{2}<\ldots<e_{v}$, and $Y$ is an arbitrary object in $U$. The lower and upper approximations of $e_{v}$ can be defined as

$$
\begin{array}{ll}
\text { Lower approximation: } & \overline{A p r}\left(e_{v}\right)=\bigcup\left\{Y \in U / R(Y) \leq e_{v}\right\} \text {; } \\
\text { Upper approximation: } \overline{A \operatorname{pr}}\left(e_{v}\right)=\bigcup\left\{Y \in U / R(Y) \geq e_{v}\right\} & \text {. }
\end{array}
$$

\section{Second step: Computing lower and upper limits of the rough number}

A group of expert judgments can be expressed by rough lower and upper limits (i.e., $\left.\underline{\operatorname{Lim}}\left(e_{v}\right), \overline{\operatorname{Lim}}\left(e_{v}\right)\right)$, and these values are used to compute the mean of elements in the lower and upper approximations, respectively: 


$$
\underline{\operatorname{Lim}}\left(e_{v}\right)=\frac{\sum_{i=1}^{N_{L}} x_{i}}{N_{L}}, \overline{\operatorname{Lim}}\left(e_{v}\right)=\frac{\sum_{i=1}^{N_{U}} y_{i}}{N_{U}},
$$

where $x_{i}$ and $y_{i}$ denote the elements in the lower and upper approximation of $e_{v}$, respectively. $N_{L}$ and $N_{U}$ represent the total number of objects involved in the lower and upper approximations of $e_{v}$, respectively.

\section{Third step: Obtaining the interval of the rough number}

Using Eqs. (B1)-(B3), the knowledge of the domain experts can be converted into a set of rough numbers $\mathrm{RN}\left(e_{v}\right)$ :

$$
R N\left(e_{v}\right)=\left[e_{v}^{L}, e_{v}^{U}\right]=\left[\underline{\operatorname{Lim}}\left(e_{v}\right), \overline{\operatorname{Lim}}\left(e_{v}\right)\right] .
$$

In addition, assume there are two rough numbers $R N(\alpha)=[\underline{\operatorname{Lim}}(\alpha), \overline{\operatorname{Lim}}(\alpha)]$ and $R N(\beta)=[\operatorname{Lim}(\beta), \overline{\operatorname{Lim}}(\beta)]$. Because $\delta$ is a nonzero constant, the arithmetic operations of the rough number can be expressed as follows (Song, Ming, \& Liu, 2017a; Song, Ming, \& $\mathrm{Wu}, 2013$; Song, Xu, \& Liu, 2017b):

$$
\begin{aligned}
R N(\alpha) \times \delta=[\underline{\operatorname{Lim}}(\alpha), \overline{\operatorname{Lim}}(\alpha)] \times \delta=[\underline{\operatorname{Lim}}(\alpha) \times \delta, \overline{\operatorname{Lim}}(\alpha) \times \delta] \\
\begin{aligned}
R N(\alpha)+R N(\beta) & =[\underline{\operatorname{Lim}}(\alpha), \overline{\operatorname{Lim}}(\alpha)]+[\underline{\operatorname{Lim}}(\beta), \overline{\operatorname{Lim}}(\beta)] \\
& =[\underline{\operatorname{Lim}}(\alpha)+\underline{\operatorname{Lim}}(\beta), \overline{\operatorname{Lim}}(\alpha)+\overline{\operatorname{Lim}}(\beta)] ; \\
R N(\alpha) \times R N(\beta) & =[\underline{\operatorname{Lim}}(\alpha), \overline{\operatorname{Lim}}(\alpha)] \times[\underline{\operatorname{Lim}}(\beta), \overline{\operatorname{Lim}}(\beta)] \\
& =[\underline{\operatorname{Lim}}(\alpha) \times \underline{\operatorname{Lim}}(\beta), \overline{\operatorname{Lim}}(\alpha) \times \overline{\operatorname{Lim}}(\beta)] .
\end{aligned}
\end{aligned}
$$

\section{Fourth step: Converting the rough number into a crisp value}

To compare analyses results or rankings, we can use the following equation to change the rough number into a crisp value:

$$
e_{v}^{d e R}=\frac{\left[e_{v}^{L}+e_{v}^{U}\right]}{2} / 2 .
$$

\section{APPENDIX B.2}

\section{Rough DEMATEL-based ANP approach}

This method involves seven steps:

\section{First step: Obtaining a rough initial influence-relationship matrix $\tilde{\boldsymbol{A}}$}

Suppose we have $n$ factors in the evaluation system, and $k$ domain experts are asked to evaluate the crisp direct-influence degree that dimension or criterion $i$ has on dimension or criterion $j$ using a scale from 0 to 4 (no influence to very strong influence). We then use Eqs. (B1)-(B7) to calculate the rough number among the $k$ respondents to obtain a rough initial influence-relationship matrix $\tilde{\boldsymbol{A}}=\left[\tilde{a}_{i j}\right]_{n \times n}=\left[a_{i j}^{L}, a_{i j}^{U}\right]_{n \times n}$. 


\section{Second step: Building the normalized rough-influence matrix $\tilde{D}$}

The rough-influence matrix $\tilde{\boldsymbol{D}}$ is normalized on the rough initial-relationship matrix $\tilde{\boldsymbol{A}}$ using the following:

$$
\begin{aligned}
& \tilde{\boldsymbol{D}}=\varepsilon \times \tilde{\boldsymbol{A}} \\
& \varepsilon=\min \left\{1 / \max _{i} \sum_{j=1}^{n} a_{i j}^{U}, 1 / \max _{j} \sum_{i=1}^{n} a_{i j}^{U}\right\}, i, j \in\{1,2, \ldots, n\},
\end{aligned}
$$

where $\tilde{\boldsymbol{D}}=\left[\tilde{d}_{i j}\right]_{n \times n}=\left[d_{i j}^{L}, d_{i j}^{U}\right], 0 \leq \tilde{d}_{i j}<1$. The sum of one column or one row is equal to 1 (but not all) in $\sum_{j=1}^{n} d_{i j}^{U}$ and $\sum_{i=1}^{n} d_{i j}^{U}$.

\section{Third step: Obtaining the rough total-influence matrix $\tilde{\boldsymbol{T}}$}

The rough total-influence matrix $\tilde{\boldsymbol{T}}$ can be obtained by summing the rough direct-influences and the rough indirect-influences using the following equation:

$$
\begin{aligned}
\tilde{\boldsymbol{T}} & =\tilde{\boldsymbol{D}}+\tilde{\boldsymbol{D}}^{2}+\tilde{\boldsymbol{D}}^{3}+\ldots+\tilde{\boldsymbol{D}}^{\Theta} \\
& =\tilde{\boldsymbol{D}}\left(\boldsymbol{I}+\tilde{\boldsymbol{D}}+\tilde{\boldsymbol{D}}^{2}+\ldots+\tilde{\boldsymbol{D}}^{\Theta-1}\right)\left[(\boldsymbol{I}-\tilde{\boldsymbol{D}})(\boldsymbol{I}-\tilde{\boldsymbol{D}})^{-1}\right] \\
& =\tilde{\boldsymbol{D}}\left(\boldsymbol{I}-\tilde{\boldsymbol{D}}^{\Theta}\right)(\boldsymbol{I}-\tilde{\boldsymbol{D}})^{-1} \\
& =\tilde{\boldsymbol{D}}(\boldsymbol{I}-\tilde{\boldsymbol{D}})^{-1}, \text { when } \Theta \rightarrow \infty, \tilde{\boldsymbol{D}}^{\Theta}=[0]_{n \times n},
\end{aligned}
$$

where $\boldsymbol{I}$ is the identity matrix.

\section{Fourth step: Building the rough influence-network relation map (RINRM)}

The row and column sums of the rough total-influence matrix $\tilde{\boldsymbol{T}}$ can be obtained using two vectors $\tilde{\boldsymbol{p}}$ and $\tilde{\boldsymbol{q}}$, respectively:

$$
\begin{aligned}
& \tilde{\boldsymbol{T}}=\left[\tilde{t}_{i j}\right]_{n \times n}=\left[t_{i j}^{L}, t_{i j}^{U}\right], \quad i, j \in\{1,2, \ldots, n\} \\
& \tilde{\boldsymbol{p}}=\left[\tilde{p}_{i}\right]_{n \times 1}=\left[\sum_{j=1}^{n} t_{i j}^{L}, \sum_{j=1}^{n} t_{i j}^{U}\right]_{n \times 1}, \tilde{\boldsymbol{q}}=\left[\tilde{q}_{j}\right]_{n \times 1}=\left[\sum_{i=1}^{n} t_{i j}^{L}, \sum_{i=1}^{n} t_{i j}^{U}\right]_{1 \times n}^{\prime},
\end{aligned}
$$

where the superscript' denotes transposition.

$\tilde{\boldsymbol{p}}$ is the row sum $\sum_{j=1}^{n} \tilde{t}_{i j}$ of the matrix $\tilde{\boldsymbol{T}}$ that denotes the sum of the rough total influence that dimension or criterion $i$ has on the other dimensions or criteria. $\tilde{\boldsymbol{q}}$ is the row sum $\sum_{i=1}^{n} \tilde{t}_{i j}$ of the matrix $\tilde{\boldsymbol{T}}$ that denotes the sum of the rough total influence that dimension or criterion $i$ receives from other dimensions or criteria.

Moreover, the prominence $(\tilde{\boldsymbol{p}}+\tilde{\boldsymbol{q}})$ is the rough total influence that dimension or criterion $i$ has in the evaluation system. The net cause-effect $(\tilde{\boldsymbol{p}}-\tilde{\boldsymbol{q}})$ is the rough total influence of dimension or criterion $i$ that has a rough net influence on the other dimensions or criteria. When $(\tilde{\boldsymbol{p}}-\tilde{\boldsymbol{q}})$ is positive, dimension or criterion $i$ has a rough net influence on the other dimensions or criteria; if it is negative, there is a rough net influence on dimension or criterion $i$ from the other dimensions or criteria. 


\section{Fifth step: Building a rough unweighted supermatrix $\tilde{W}$}

Firstly, each level is normalized using the total degree of influence based on the totalinfluence relationship matrix, where $m$ is the number of criteria within a dimension and $\boldsymbol{T}_{c}^{i j}$ is a $m_{i} \times m_{j}$ matrix. Then, $\tilde{\boldsymbol{T}}_{c}$ is normalized using the total degree of influence to obtain $\tilde{T}_{c}^{\alpha}=\left[\tilde{T}_{c}^{\alpha i j}\right]=\left[t_{c}^{\alpha L}, t_{c}^{\alpha U}\right]_{n \times n \mid m<n, \sum_{j=1}^{m} m_{j}=n}$. Finally, the rough total-influence relationship matrix is normalized and transposed to obtain the rough unweighted supermatrix according to the relevant relationship between dimensions:

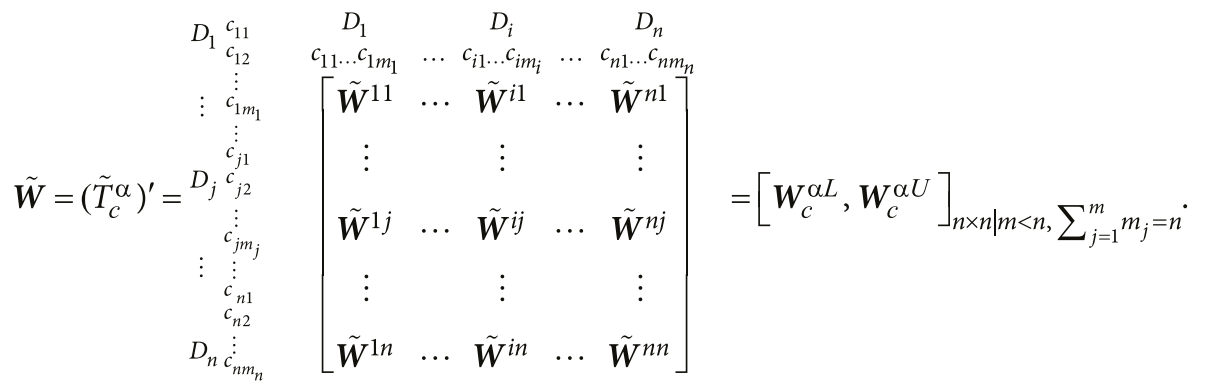

\section{Sixth step: Obtaining rough weighted supermatrix $\tilde{\boldsymbol{W}}^{\phi}$}

The rough weighted supermatrix $\tilde{\boldsymbol{W}}^{\phi}$ is obtained by normalizing the rough total-influence matrix $\tilde{\boldsymbol{T}}_{D}^{\alpha}$ using the rough unweighted supermatrix $\tilde{\boldsymbol{W}}$, as shown in the following equations:

$$
\widetilde{\boldsymbol{T}}_{D}^{\alpha}=\left[\begin{array}{ccccc}
\sim_{t}^{11} & \cdots & \tilde{t}_{D}^{1 j} & \cdots & \tilde{t}_{D}^{1 m} \\
\vdots & & \vdots & & \vdots \\
\tilde{t}_{D}^{i 1} & \cdots & \sim_{t}^{i j} & \cdots & \sim_{t_{D}^{i m}} \\
\vdots & & \vdots & & \vdots \\
\tilde{t}_{D}^{m 1} & \cdots & \sim^{m j} & \cdots & \sim_{D}^{m m} \\
t_{D} & \cdots & \cdots & t_{D}
\end{array}\right]=\left[\boldsymbol{T}_{D}^{\alpha L}, \boldsymbol{T}_{D}^{\alpha U}\right]_{m \times m}
$$

Here, $\boldsymbol{T}_{D}^{\alpha L}$ is taken as an example of how to normalize the rough total-influence matrix $\tilde{\boldsymbol{T}}_{D}$ of dimensions and obtain a new normalized rough total-influence matrix $\boldsymbol{T}_{D}^{\alpha}$ (as adjustment coefficient) of dimensions:

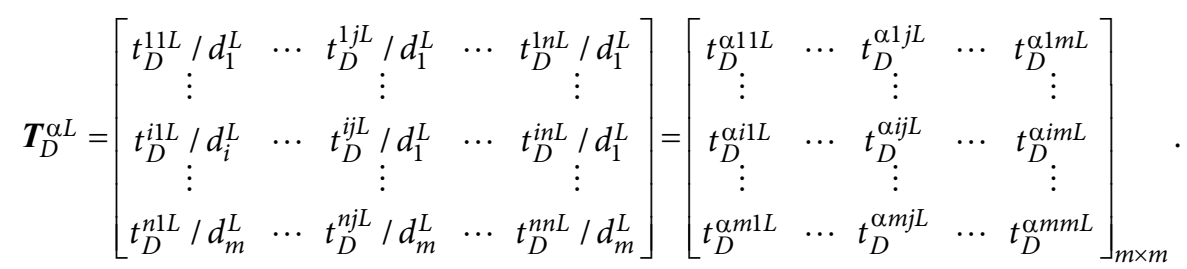

We then multiply the normalized total influence matrix $\boldsymbol{T}_{D}^{\alpha}$ of dimensions by the unweighted supermatrix $\tilde{\boldsymbol{W}}$ to obtain the newly weighted supermatrix $\tilde{\boldsymbol{W}}^{\phi}$ (i.e., the normalized matrix):

$$
\boldsymbol{W}^{\phi L}=\boldsymbol{T}_{D}^{\alpha L} \boldsymbol{W}^{L}=\left[\begin{array}{ccccc}
t_{D}^{\alpha 11 \mathrm{~L}} \times \boldsymbol{W}^{11 \mathrm{~L}} & \cdots & t_{D}^{\alpha i 1 \mathrm{~L}} \times \boldsymbol{W}^{i 1 L} & \cdots & t_{D}^{\alpha m 1 L} \times \boldsymbol{W}^{m 1 L} \\
\vdots & & \vdots & & \vdots \\
t_{D}^{\alpha 1 j L} \times \boldsymbol{W}^{1 j L} & \cdots & t_{D}^{\alpha i j L} \times \boldsymbol{W}^{i j L} & \cdots & t_{D}^{\alpha m j L} \times \boldsymbol{W}^{m j L} \\
\vdots & & \vdots & & \vdots \\
t_{D}^{\alpha 1 m L} \times \boldsymbol{W}^{1 m L} & \cdots & t_{D}^{\alpha i m L} \times \boldsymbol{W}^{i m L} & \cdots & t_{D}^{\alpha m m L} \times \boldsymbol{W}^{m m L}
\end{array}\right]_{n \times n \mid m<n, \sum_{j=1}^{m} m_{j}=n}
$$


Seventh step: Limiting the rough weighted supermatrix $\lim _{\Omega \rightarrow \infty}\left(\tilde{\boldsymbol{W}}^{\phi}\right)^{\Omega}$

The rough weighted supermatrix $\tilde{\boldsymbol{W}}^{\phi}$ is multiplied by itself several times to obtain a limited rough weighted matrix $\lim _{\Omega \rightarrow \infty}\left(\tilde{W}^{\phi}\right)^{\Omega}$. Then, the influential weights of each criterion can be obtained by $\lim _{\Omega \rightarrow \infty}\left(\boldsymbol{W}^{\phi L}\right)^{\Omega}$ and $\lim _{\Omega \rightarrow \infty}\left(\boldsymbol{W}^{\phi U}\right)^{\Omega}$, respectively. That is, the influential weights of DANP can be obtained using the limited rough weighted supermatrix $\tilde{\boldsymbol{W}}^{\phi}$ with power $\boldsymbol{\Omega}$ (with $\boldsymbol{\Omega}$ representing any number). In addition, the adjusted ratio of rough influential weights can be obtained using the ratios of the matrixes $\boldsymbol{T}_{D}^{L}$ and $\boldsymbol{T}_{D}^{U}$ in $\tilde{\boldsymbol{T}}_{D}$. The summation of the upper and lower numbers in the rough influential weights equals one and less than one, respectively. This completes the process of rough DANP.

\section{APPENDIX B.3}

\section{Modified COPRAS-G method}

This method involves five steps:

\section{First step: Preparing a rough performance $\tilde{Z}$}

First, the experts use a scale of natural language (i.e., very bad/dissatisfactory (0) to very good/satisfactory (1)) to provide a performance score for each criterion of the alternatives in the questionnaire. Then, the performance of each alternative is obtained as the rough performance $\tilde{\boldsymbol{Z}}=\left[\tilde{z}_{k j}\right]=\left[z_{i j}^{L}, z_{i j}^{U}\right]_{k \times n}$ by using the rough number. That is, the interval value of performance is obtained from the rough number, which reflects the group uncertainty of domain knowledge or the incomplete information available to decision makers. The rough performance is given by

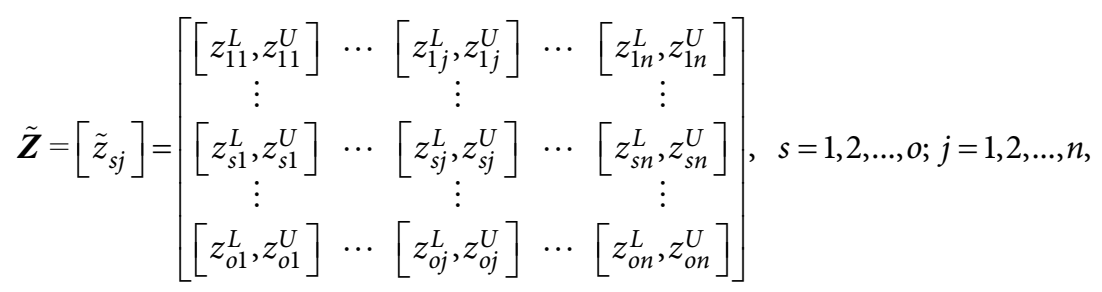

where $z_{s j}^{L}$ and $z_{s j}^{U}$ are the lower and upper limits for criterion $j$ respective to alternative $s$, respectively.

\section{Second step: Normalizing the decision-making matrix $\tilde{B}$ using the aspiration level}

In the entire evaluation process, we adopt 0 and 10 as the values of lowest and highest aspiration, respectively. This setting can help decision makers avoid "choosing the best among inferior choices/options/alternatives (i.e., avoid picking the best apple among a barrel of rotten apples)."

$$
\begin{aligned}
& \tilde{\boldsymbol{B}}=\left[\tilde{b}_{s j}\right]=\left[b_{s j}^{L}, b_{s j}^{U}\right], \quad s=1,2, \ldots, 0 ; j=1,2, \ldots, n ; \\
& b_{s j}^{L}=\frac{z_{s j}^{L}}{z_{j}^{\text {Uaspire }}-z_{j}^{\text {Uworst }}}, \quad b_{s j}^{U}=\frac{z_{s j}^{U}}{z_{j}^{\text {Uaspire }}-z_{j}^{\text {Uworst }}}, z_{j}^{\text {Uaspire }}=1 ; z_{j}^{\text {Uworst }}=0 .
\end{aligned}
$$




\section{Third step: Calculating the interval grade of gray relation}

The degree of gray relation in the lower and upper bounds for the aspiration values are calculated using

$$
\begin{aligned}
\gamma\left(b_{j}^{\text {Uaspire }}, b_{s j}^{L}\right) & =\frac{\min _{s} \min _{j}\left|b_{j}^{\text {Uaspire }}-b_{s j}^{L}\right|+\lambda \max _{s} \max _{j}\left|b_{j}^{\text {Uaspire }}-b_{s j}^{L}\right|}{\left|b_{j}^{\text {Uaspire }}-b_{s j}^{L}\right|+\lambda \max _{s} \max _{j}\left|b_{j}^{\text {Uaspire }}-b_{s j}^{L}\right|} \\
\gamma\left(b_{j}^{\text {Uaspire }}, b_{s j}^{U}\right) & =\frac{\min _{s} \min _{j}\left|b_{j}^{\text {Uaspire }}-b_{s j}^{U}\right|+\lambda \max _{s} \max _{j}\left|b_{j}^{\text {Uaspire }}-b_{s j}^{U}\right|}{\left|b_{j}^{\text {Uaspire }}-b_{s j}^{U}\right|+\lambda \max _{s} \max _{j}\left|b_{j}^{\text {Uaspire }}-b_{s j}^{U}\right|} .
\end{aligned}
$$

where $\lambda$ is an adjustment coefficient (generally set to 0.5$)$ and the interval grade of gray relation $\gamma\left(\left(b_{j}^{\text {Uaspire }}, b_{s j}^{L}\right) ;\left(b_{j}^{\text {Uaspire }}, b_{s j}^{U}\right)\right)$ is

$$
\gamma\left(\left(b^{\text {Uaspire }}, b_{s}^{L}\right) ;\left(b^{\text {Uaspire }}, b_{s}^{U}\right)\right)=\sum_{j=1}^{n} w_{j}\left(\gamma\left(b_{j}^{\text {Uaspire }}, b_{s j}^{L}\right) ; \gamma\left(b_{j}^{\text {Uaspire }}, b_{s j}^{U}\right)\right),
$$

where $\gamma\left(b^{\text {Uaspire }}, b_{s}^{L}\right)=\sum_{j=1}^{n} w_{j} \gamma\left(b_{j}^{\text {Uaspire }}, b_{s j}^{L}\right), \gamma\left(b^{\text {Uaspire }}, b_{s}^{U}\right)=\sum_{j=1}^{n} w_{j} \gamma\left(b_{j}^{\text {Uaspire }}, b_{s j}^{U}\right)$, and the aspiration levels of $b^{\text {Uaspire }}$ and $b_{j}^{\text {Uaspire }}$ equal 1 .

\section{Fourth step: Calculating the relative significance $\boldsymbol{H}_{\mathrm{k}}$}

The relative significance $H_{s}$ indicates the deroughness degree of satisfaction for each criterion for alternative $k$. The relative significance $H_{s}$ of the criteria are calculated as follows:

$$
H_{s}=\frac{1}{2}\left(\gamma\left(b^{\text {Uaspire }}, b_{s}^{L}\right)+\gamma\left(b^{\text {Uaspire }}, b_{s}^{U}\right)\right) \text {. }
$$

\section{Fifth step: Calculating the utility ratio of each alternative}

Finally, the utility degree $N_{s}$ of each alternative $s$ between relative significance and aspiration level is calculated using

where $B^{\text {Uaspire }}$ is the aspired alternative.

$$
N_{s}^{\text {aspire }}=\frac{H_{s}}{B^{\text {Uaspire }}} \times 100 \%,
$$




\section{APPENDIX C}

\section{Matrix information}

Table C.1. Rough total-influence relationship matrix

\begin{tabular}{|c|c|c|c|c|c|c|c|c|c|c|}
\hline & $C_{11}$ & $C_{12}$ & $C_{13}$ & $C_{21}$ & $C_{22}$ & $C_{23}$ & $C_{31}$ & $C_{32}$ & $C_{33}$ & $C_{34}$ \\
\hline$C_{11}$ & {$[0.17,0.94]$} & {$[0.20,0.95]$} & {$[0.19,0.89]$} & {$[0.24,1.02]$} & {$[0.20,0.96]$} & {$[0.21,1.01]$} & {$[0.26,1.01]$} & {$[0.24,1.01]$} & {$[0.22,0.97]$} & {$[0.22,0.97]$} \\
\hline$C_{12}$ & {$[0.19,0.94]$} & {$[0.11,0.77]$} & {$[0.15,0.81]$} & {$[0.21,0.93]$} & {$[0.18,0.87]$} & {$[0.20,0.92]$} & {$[0.18,0.90]$} & {$[0.15,0.89]$} & {$[0.15,0.86]$} & {$[0.15,0.87]$} \\
\hline$C_{13}$ & {$[0.15,0.81]$} & {$[0.14,0.74]$} & {$[0.07,0.61]$} & {$[0.13,0.78]$} & {$[0.12,0.73]$} & {$[0.13,0.78]$} & {$[0.14,0.76]$} & {$[0.13,0.77]$} & {$[0.11,0.73]$} & {$[0.11,0.74]$} \\
\hline$C_{21}$ & {$[0.21,0.99]$} & {$[0.19,0.91]$} & {$[0.14,0.83]$} & {$[0.13,0.87]$} & {$[0.20,0.91]$} & {$[0.20,0.96]$} & {$[0.22,0.96]$} & {$[0.19,0.95]$} & {$[0.17,0.91]$} & {$[0.18,0.92]$} \\
\hline$C_{22}$ & {$[0.17,0.89]$} & {$[0.15,0.83]$} & {$[0.13,0.76]$} & {$[0.17,0.89]$} & {$[0.09,0.74]$} & {$[0.16,0.88]$} & {$[0.16,0.88]$} & {$[0.14,0.87]$} & {$[0.12,0.84]$} & {$[0.12,0.83]$} \\
\hline$C_{23}$ & {$[0.21,0.96]$} & {$[0.20,0.89]$} & {$[0.16,0.82]$} & {$[0.22,0.95]$} & {$[0.19,0.89]$} & {$[0.12,0.84]$} & {$[0.19,0.93]$} & {$[0.17,0.93]$} & {$[0.15,0.88]$} & {$[0.16,0.89]$} \\
\hline$C_{31}$ & {$[0.25,0.99]$} & {$[0.19,0.89]$} & {$[0.17,0.83]$} & {$[0.22,0.96]$} & {$[0.19,0.88]$} & {$[0.20,0.94]$} & {$[0.15,0.85]$} & {$[0.21,0.94]$} & {$[0.19,0.91]$} & {$[0.21,0.92]$} \\
\hline$C_{32}$ & {$[0.23,0.98]$} & {$[0.17,0.88]$} & {$[0.15,0.82]$} & {$[0.19,0.94]$} & {$[0.17,0.88]$} & {$[0.20,0.94]$} & {$[0.22,0.95]$} & {$[0.12,0.84]$} & {$[0.18,0.90]$} & {$[0.19,0.91]$} \\
\hline$C_{33}$ & {$[0.23,0.97]$} & {$[0.18,0.87]$} & {$[0.15,0.80]$} & {$[0.20,0.93]$} & {$[0.16,0.86]$} & {$[0.19,0.92]$} & {$[0.23,0.93]$} & {$[0.20,0.93]$} & {$[0.11,0.79]$} & {$[0.18,0.90]$} \\
\hline$C_{34}$ & {$[0.22,0.94]$} & {$[0.17,0.84]$} & {$[0.14,0.77]$} & {$[0.19,0.91]$} & {$[0.17,0.85]$} & {$[0.19,0.90]$} & {$[0.19,0.90]$} & {$[0.19,0.90]$} & {$[0.16,0.87]$} & {$[0.11,0.78]$} \\
\hline
\end{tabular}

Table C.2. Rough unweighted supermatrix

\begin{tabular}{|l|c|c|c|c|c|c|c|c|c|c|}
\hline & $\mathrm{C}_{11}$ & $\mathrm{C}_{12}$ & $\mathrm{C}_{13}$ & $\mathrm{C}_{21}$ & $\mathrm{C}_{22}$ & $\mathrm{C}_{23}$ & $\mathrm{C}_{31}$ & $\mathrm{C}_{32}$ & $\mathrm{C}_{33}$ & $\mathrm{C}_{34}$ \\
\hline $\mathrm{C}_{11}$ & {$[0.30,0.34]$} & {$[0.43,0.37]$} & {$[0.42,0.37]$} & {$[0.39,0.36]$} & {$[0.37,0.36]$} & {$[0.37,0.36]$} & {$[0.41,0.37]$} & {$[0.41,0.37]$} & {$[0.41,0.37]$} & {$[0.42,0.37]$} \\
\hline $\mathrm{C}_{12}$ & {$[0.36,0.34$} & {$[0.24,0.31]$} & {$[0.39,0.34]$} & {$[0.35,0.33]$} & {$[0.34,0.33]$} & {$[0.35,0.33]$} & {$[0.31,0.33]$} & {$[0.31,0.33]$} & {$[0.31,0.33]$} & {$[0.32,0.33]$} \\
\hline $\mathrm{C}_{13}$ & {$[0.34,0.32]$} & {$[0.33,0.32]$} & {$[0.19,0.28]$} & {$[0.25,0.30]$} & {$[0.29,0.31]$} & {$[0.27,0.31]$} & {$[0.28,0.31]$} & {$[0.28,0.31]$} & {$[0.27,0.30]$} & {$[0.26,0.30]$} \\
\hline $\mathrm{C}_{21}$ & {$[0.37,0.34]$} & {$[0.36,0.34]$} & {$[0.34,0.34]$} & {$[0.25,0.32]$} & {$[0.39,0.35]$} & {$[0.41,0.35]$} & {$[0.37,0.34]$} & {$[0.34,0.34]$} & {$[0.36,0.34]$} & {$[0.35,0.34]$} \\
\hline $\mathrm{C}_{22}$ & {$[0.31,0.32]$} & {$[0.30,0.32]$} & {$[0.32,0.32]$} & {$[0.37,0.33]$} & {$[0.21,0.30]$} & {$[0.36,0.33]$} & {$[0.31,0.32]$} & {$[0.30,0.32]$} & {$[0.29,0.32]$} & {$[0.31,0.32]$} \\
\hline $\mathrm{C}_{23}$ & {$[0.32,0.34]$} & {$[0.34,0.34]$} & {$[0.34,0.34]$} & {$[0.38,0.35]$} & {$[0.39,0.35]$} & {$[0.23,0.31]$} & {$[0.33,0.34]$} & {$[0.36,0.34]$} & {$[0.35,0.34]$} & {$[0.34,0.34]$} \\
\hline $\mathrm{C}_{31}$ & {$[0.27,0.26]$} & {$[0.29,0.26]$} & {$[0.28,0.25]$} & {$[0.29,0.26]$} & {$[0.29,0.26]$} & {$[0.28,0.26]$} & {$[0.19,0.23]$} & {$[0.31,0.26]$} & {$[0.31,0.26]$} & {$[0.29,0.26]$} \\
\hline $\mathrm{C}_{32}$ & {$[0.25,0.25]$} & {$[0.24,0.25]$} & {$[0.27,0.26]$} & {$[0.24,0.25]$} & {$[0.26,0.26]$} & {$[0.25,0.26]$} & {$[0.28,0.26]$} & {$[0.17,0.23]$} & {$[0.28,0.26]$} & {$[0.29,0.26]$} \\
\hline $\mathrm{C}_{33}$ & {$[0.24,0.24]$} & {$[0.23,0.24]$} & {$[0.23,0.24]$} & {$[0.23,0.24]$} & {$[0.23,0.24]$} & {$[0.22,0.24]$} & {$[0.25,0.25]$} & {$[0.26,0.25]$} & {$[0.15,0.22]$} & {$[0.25,0.25]$} \\
\hline $\mathrm{C}_{34}$ & {$[0.24,0.25]$} & {$[0.24,0.25]$} & {$[0.22,0.25]$} & {$[0.24,0.24]$} & {$[0.22,0.24]$} & {$[0.24,0.25]$} & {$[0.28,0.25]$} & {$[0.26,0.25]$} & {$[0.25,0.25]$} & {$[0.17,0.23]$} \\
\hline
\end{tabular}

Table C.3 Rough weighted supermatrix

\begin{tabular}{|c|c|c|c|c|c|c|c|c|c|c|}
\hline & $\mathrm{C}_{11}$ & $\mathrm{C}_{12}$ & $\mathrm{C}_{13}$ & $\mathrm{C}_{21}$ & $\mathrm{C}_{22}$ & $\mathrm{C}_{23}$ & $\mathrm{C}_{31}$ & $\mathrm{C}_{32}$ & $\mathrm{C}_{33}$ & $\mathrm{C}_{34}$ \\
\hline $\mathrm{C}_{11}$ & {$[0.09,0.11]$} & {$[0.13,0.12]$} & {$[0.13,0.12]$} & {$[0.14,0.12]$} & {$[0.13,0.12]$} & {$[0.13,0.12]$} & {$[0.14,0.12]$} & {$[0.14,0.12]$} & {$[0.14,0.12]$} & {$[0.14,0.12]$} \\
\hline $\mathrm{C}_{12}$ & {$[0.11,0.11]$} & {$[0.07,0.10]$} & {$[0.12,0.11]$} & {$[0.12,0.11]$} & {$[0.12,0.11]$} & {$[0.12,0.11]$} & {$[0.11,0.11]$} & {$[0.11,0.11]$} & {$[0.11,0.11]$} & {$[0.11,0.11]$} \\
\hline $\mathrm{C}_{13}$ & {$[0.10,0.10]$} & {$[0.10,0.10]$} & {$[0.06,0.09]$} & {$[0.09,0.10]$} & {$[0.10,0.10]$} & {$[0.09,0.10]$} & {$[0.10,0.10]$} & {$[0.10,0.10]$} & {$[0.09,0.10]$} & {$[0.09,0.10]$} \\
\hline $\mathrm{C}_{21}$ & {$[0.13,0.12]$} & {$[0.13,0.12]$} & {$[0.12,0.12]$} & {$[0.08,0.11]$} & {$[0.13,0.12]$} & {$[0.13,0.12]$} & {$[0.12,0.12]$} & {$[0.12,0.12]$} & {$[0.12,0.12]$} & {$[0.12,0.12]$} \\
\hline $\mathrm{C}_{22}$ & {$[0.11,0.11]$} & {$[0.11,0.11]$} & {$[0.11,0.11]$} & {$[0.12,0.11]$} & {$[0.07,0.10]$} & {$[0.12,0.11]$} & {$[0.11,0.11]$} & {$[0.10,0.11]$} & {$[0.10,0.11]$} & {$[0.11,0.11]$} \\
\hline $\mathrm{C}_{23}$ & {$[0.11,0.12]$} & {$[0.12,0.12]$} & {$[0.12,0.12]$} & {$[0.12,0.12]$} & {$[0.13,0.12]$} & {$[0.08,0.10]$} & {$[0.11,0.11]$} & {$[0.12,0.12]$} & {$[0.12,0.12]$} & {$[0.12,0.11]$} \\
\hline $\mathrm{C}_{31}$ & {$[0.09,0.09]$} & {$[0.10,0.09]$} & {$[0.10,0.09]$} & {$[0.09,0.09]$} & {$[0.10,0.09]$} & {$[0.09,0.09]$} & {$[0.06,0.08]$} & {$[0.10,0.09]$} & {$[0.10,0.09]$} & {$[0.09,0.09]$} \\
\hline $\mathrm{C}_{32}$ & {$[0.09,0.09]$} & {$[0.08,0.09]$} & {$[0.09,0.09]$} & {$[0.08,0.09]$} & {$[0.08,0.09]$} & {$[0.08,0.09]$} & {$[0.09,0.09]$} & {$[0.05,0.08]$} & {$[0.09,0.09]$} & {$[0.09,0.09]$} \\
\hline $\mathrm{C}_{33}$ & {$[0.08,0.08]$} & {$[0.08,0.08]$} & {$[0.08,0.08]$} & {$[0.07,0.08]$} & {$[0.07,0.08]$} & {$[0.07,0.08]$} & {$[0.08,0.08]$} & {$[0.08,0.08]$} & {$[0.05,0.07]$} & {$[0.08,0.08]$} \\
\hline $\mathrm{C}_{34}$ & {$[0.08,0.08]$} & {$[0.08,0.08]$} & {$[0.08,0.08]$} & {$[0.08,0.08]$} & {$[0.07,0.08]$} & {$[0.08,0.08]$} & {$[0.09,0.08]$} & {$[0.08,0.08]$} & {$[0.08,0.08]$} & {$[0.05,0.07]$} \\
\hline
\end{tabular}


Table C.4. Rough stable supermatrix

\begin{tabular}{|c|c|c|c|c|c|c|c|c|c|c|}
\hline & $\mathrm{C}_{11}$ & $\mathrm{C}_{12}$ & $\mathrm{C}_{13}$ & $\mathrm{C}_{21}$ & $\mathrm{C}_{22}$ & $\mathrm{C}_{23}$ & $\mathrm{C}_{31}$ & $\mathrm{C}_{32}$ & $\mathrm{C}_{33}$ & $\mathrm{C}_{34}$ \\
\hline $\mathrm{C}_{11}$ & {$[0.13,0.12]$} & {$[0.13,0.12]$} & {$[0.13,0.12]$} & {$[0.13,0.12]$} & {$[0.13,0.12]$} & {$[0.13,0.12]$} & {$[0.13,0.12]$} & {$[0.13,0.12]$} & {$[0.13,0.12]$} & {$[0.13,0.12]$} \\
\hline $\mathrm{C}_{12}$ & {$[0.11,0.11]$} & {$[0.11,0.11]$} & {$[0.11,0.11]$} & {$[0.11,0.11]$} & {$[0.11,0.11]$} & {$[0.11,0.11]$} & {$[0.11,0.11]$} & {$[0.11,0.11]$} & {$[0.11,0.11]$} & {$[0.11,0.11]$} \\
\hline $\mathrm{C}_{13}$ & {$[0.09,0.10]$} & {$[0.09,0.10]$} & {$[0.09,0.10]$} & {$[0.09,0.10]$} & {$[0.09,0.10]$} & {$[0.09,0.10]$} & {$[0.09,0.10]$} & {$[0.09,0.10]$} & {$[0.09,0.10]$} & {$[0.09,0.10]$} \\
\hline $\mathrm{C}_{21}$ & {$[0.12,0.12]$} & {$[0.12,0.12]$} & {$[0.12,0.12]$} & {$[0.12,0.12]$} & {$[0.12,0.12]$} & {$[0.12,0.12]$} & {$[0.12,0.12]$} & {$[0.12,0.12]$} & {$[0.12,0.12]$} & {$[0.12,0.12]$} \\
\hline $\mathrm{C}_{22}$ & {$[0.11,0.11]$} & {$[0.11,0.11]$} & {$[0.11,0.11]$} & {$[0.11,0.11]$} & {$[0.11,0.11]$} & {$[0.11,0.11]$} & {$[0.11,0.11]$} & {$[0.11,0.11]$} & {$[0.11,0.11]$} & {$[0.11,0.11]$} \\
\hline $\mathrm{C}_{23}$ & {$[0.11,0.11]$} & {$[0.11,0.11]$} & {$[0.11,0.11]$} & {$[0.11,0.11]$} & {$[0.11,0.11]$} & {$[0.11,0.11]$} & {$[0.11,0.11]$} & {$[0.11,0.11]$} & {$[0.11,0.11]$} & {$[0.11,0.11]$} \\
\hline $\mathrm{C}_{31}$ & {$[0.09,0.09]$} & {$[0.09,0.09]$} & {$[0.09,0.09]$} & {$[0.09,0.09]$} & {$[0.09,0.09]$} & {$[0.09,0.09]$} & {$[0.09,0.09]$} & {$[0.09,0.09]$} & {$[0.09,0.09]$} & {$[0.09,0.09]$} \\
\hline $\mathrm{C}_{32}$ & {$[0.08,0.09]$} & {$[0.08,0.09]$} & {$[0.08,0.09]$} & {$[0.08,0.09]$} & {$[0.08,0.09]$} & {$[0.08,0.09]$} & {$[0.08,0.09]$} & {$[0.08,0.09]$} & {$[0.08,0.09]$} & {$[0.08,0.09]$} \\
\hline $\mathrm{C}_{33}$ & {$[0.08,0.08]$} & {$[0.08,0.08]$} & {$[0.08,0.08]$} & {$[0.08,0.08]$} & {$[0.08,0.08]$} & {$[0.08,0.08]$} & {$[0.08,0.08]$} & {$[0.08,0.08]$} & {$[0.08,0.08]$} & {$[0.08,0.08]$} \\
\hline $\mathrm{C}_{34}$ & {$[0.08,0.08]$} & {$[0.08,0.08]$} & {$[0.08,0.08]$} & {$[0.08,0.08]$} & {$[0.08,0.08]$} & {$[0.08,0.08]$} & {$[0.08,0.08]$} & {$[0.08,0.08]$} & {$[0.08,0.08]$} & {$[0.08,0.08]$} \\
\hline
\end{tabular}

